\title{
Deflation and the Petty Coinage Problem in the Late-Medieval Economy: The Case of Flanders, 1334-1484*
}

\author{
JoHn H. Munro \\ University of Toronto
}

\begin{abstract}
Monetary historians have debated whether too many or too few petty coins, those most needed by the general populace, were struck in medieval Europe. But exactly how many were struck can be determined only for Flanders, where petty coinage usually accounted for $1 \%$ or less of the bullion minted. These mintoutput statistics are explained in part by the demand for high-denomination coins by most merchants who supplied bullion to the mints; but equally also by the relatively small need to replace stocks of petty coin. Severe petty-coin scarcity was not likely a chronic condition in medieval Flanders; but did occur in the deflationary mid-fifteenth century, instigating innovations in state monetary policy. () 1988 Academic Press, Inc.
\end{abstract}

One of the least-well-studied aspects of European monetary history is the role of petty coinage, especially in the medieval economy. In the current but scant literature on petty coinage, we find two contradictory views: that either too much or too little was struck. Thus Herman Van der Wee $(1969$, p. 375$)$ has contended that frequently so many petty coins circulated that "under these circumstances an inflation of what we would call fiduciary currency occurred ... which resulted in a disappearance of the silver 'link' money from circulation because of actual undervaluation." In terms of the familiar Gresham's Law, therefore, the overabundant and thus "cheap" or "bad" petty coins drove out the good "dear" silver money. Philip Grierson (1976, p. 113), however, drawing upon the work of his former student Peter Spufford (1970), has stated the contrary: that medieval "moneyers preferred to strike high denominations to low ones . . . and were apt to leave the public desperately short of small change." What constituted such a shortage was not, however, specified.

Whether too much or too little petty coinage was struck in this era is

* I am greatly indebted to Peter Spufford, Charles Calomiris, Larry Neal, Alan Stahl, and an anonymous referee for their advice and assistance to me in writing this article, whose errors and omissions remain my own. 
indeed a question that cannot be easily resolved for most of Europe. Carlo Cipolla (1956, pp. 32-33), to be sure, has stated that late-medieval Italian minting policies resulted in "a chain of alternate periods of shortages of petty coins and excessive coining" from periodic debasements; and that the latter proved more beneficial than harmful in this era when "the overall supply of precious metals proved to be extremely inelastic." But again conditions of coin scarcity or excess are not really defined; and his thesis cannot be verified because Italian mint account data are too sparse. ${ }^{1}$ French mint accounts, commencing in the early 14th century (1308), have survived in far greater abundance, but with many lacunac; they are certainly incomplete for the entire kingdom. ${ }^{2}$ Only for Flanders and England do we possess mint accounts in a virtually complete, unbroken series in the late-medieval era. Regrettably the English accounts cease giving information for each coin denomination struck after June $1351 .^{3}$ Only the Flemish accounts continue to do so; and only for Flanders, therefore, can we answer the questions: how much petty coinage was struck from year to year, and what proportions of total mint outputs were struck in that form?

To understand properly the significance of this debate and the Flemish mint data, we must also (1) understand the nature of medieval minting; (2) define precisely the term "petty coin"; and (3) acquire some quantitative measure of its purchasing power in the economy of late-medieval Flanders. Virtually everywhere in medieval Europe, certainly in Flanders, minting was undertaken at least partly for profit, potentially derived from two charges imposed on coinage. ${ }^{4}$ The first was a feudal tax on minting that went directly to the prince as seigniorage. His profit, however, was only

${ }^{1}$ His thesis is too complex to reproduce here: see Cipolla (1956, pp. 27-33; and also 1963, 1982); Spengler (1966, pp. 208-214); Cannan (1926, pp. 25-31); and p. 393 below. Bernocchi (1976, Vol. 3, pp. 252-256) has published summaries of the Florentine mint accounts for silver from 1345 , but with many gaps: accounts are missing for the years $1392-1422$, 1450-1451, 1453-1463, 1465-1471, 1477-1478, 1495-1502. The Venetian mint accounts are still missing; see Lane and Mueller (1985, Chap. 10, Appendix B); for Genoa, Milan, Florence, and Venice, see Day (1978, pp. 23-35, 40-42, 53-54).

${ }^{2}$ For the French mint accounts, see Miskimim $(1963,1984)$ and Spooner (1972); they provide mint outputs only in total livres and fine marcs struck, not by coin denominations.

${ }^{3}$ For an explanation see below pp. 402-403 and n. 15. The various silver coin denominations had been differentiated in the English mint accounts from the first extant accounts, in 1234, to June 1351.

${ }^{4}$ For the numismatics and economics of the following, see Munro (1973, Chap. 1, "The Economics of Bullionism," pp. 11-36; 1979, pp. 178-187; 1983, pp. 109-126); Feavearyear (1963, pp. 1-45); Grierson (1975, pp. 94-123); De Roover (1948, pp. 220-246); Spufford (1970, pp. 29-54, 130-146); Challis (1978, pp. 1-28, 165-198); Van der Wee (1977, pp. 290-300). Prince and mint-master usually also shared another source of profit on minting: any left-over precious metals, the remèdes or "tolerances" in fineness and weight that had to be allowed, because of the mechanical crudity of coin stamping and cutting in medieval minting. See the Appendix. 
a residual revenue after paying the salaries of his monetary officials and mint inspectors and the capital costs of the mint buildings. The second fee, known as brassage, went to the mint-master, to cover his costs for copper alloys used in the coins, the production of coin dies, the wages of his employees, and any funds expended in leasing ("farming") the mint from the prince; his profit was thus also the residual amount. In return for the bullion supplied to the mint, the money-changer or merchant received payment based on the "mint price": the official monetary equivalent or traite value of the bullion coined less the deductions for seigniorage and brassage, per pound or marc $(244.75 \mathrm{~g})$ of precious metal, illustrated in Table 1 and the Appendix.

Merchants would supply bullion only if the coins received enjoyed a "premium" over their bullion contents high enough to cover the seigniorage, brassage, and transactions costs. Coins normally commanded such a premium, to circulate by "tale" or number at face value, because of their recognizability (the coin's "stamp"), portability, divisibility, and general convenience in trade. But they could do so only so long as they remained physically unimpaired, to command public confidence, and their circulating quantity did not grow beyond total public demand for coined money. ${ }^{5}$ The state (in Flanders and England) sought to protect that premium by preventing the circulation of most foreign coins and by making the mint, its licenced changers, and a few licenced jewelers the sole purchasers of bullion, banning any other bullion transactions. The mints were not, however, always willing and able to buy bullion: most would remain open only so long as the bullion influx and thus coinage revenues were large enough to cover their variable costs.

Frequently medieval princes sought to induce a greater bullion influx by a coinage debasement: reducing the coin's precious metal content, by weight and/or fineness (alloy), in order to strike a higher traite or official value of coinage from a given quantity of precious metal. That increase in the traite thus permitted the mint to increase its bullion price for the merchants, the prince's seigniorage, the mint-masters' brassageand also necessarily the coinage premium. The relationship between the physical and monetary changes, between debasement and the new traite values, was a reciprocal one, expressed by the formula: $\Delta \mathrm{T}$ (traite) $=$ $[1 /(1-x)]-1$, in which $x$ is the percentage reduction in the silver content of the penny or other coin linked to the money-of-account. Such changes can be also be seen in Table 1, for the Flemish debasement of November 1428 . Thus an $11.76 \%$ reduction in the pure silver content of the $2 \mathrm{~d}$. coin (from $1.725 \mathrm{~g}$. to $1.522 \mathrm{~g}$.) resulted in a $13.32 \%$ increase in

\footnotetext{
${ }^{5}$ Compare with the recommendation of the late 17 th-century Italian writer Geminiano Montanari that the state "not strike more [petty coins] than [are] sufficient for the use of his people, sooner striking too few than striking too many." Cited in Cipolla (1956, p. 30), Spengler (1966, p. 211), Monroe (1923, p. 98). See also p. 407, n. 23; and p. 417 , n. 50 below.
} 


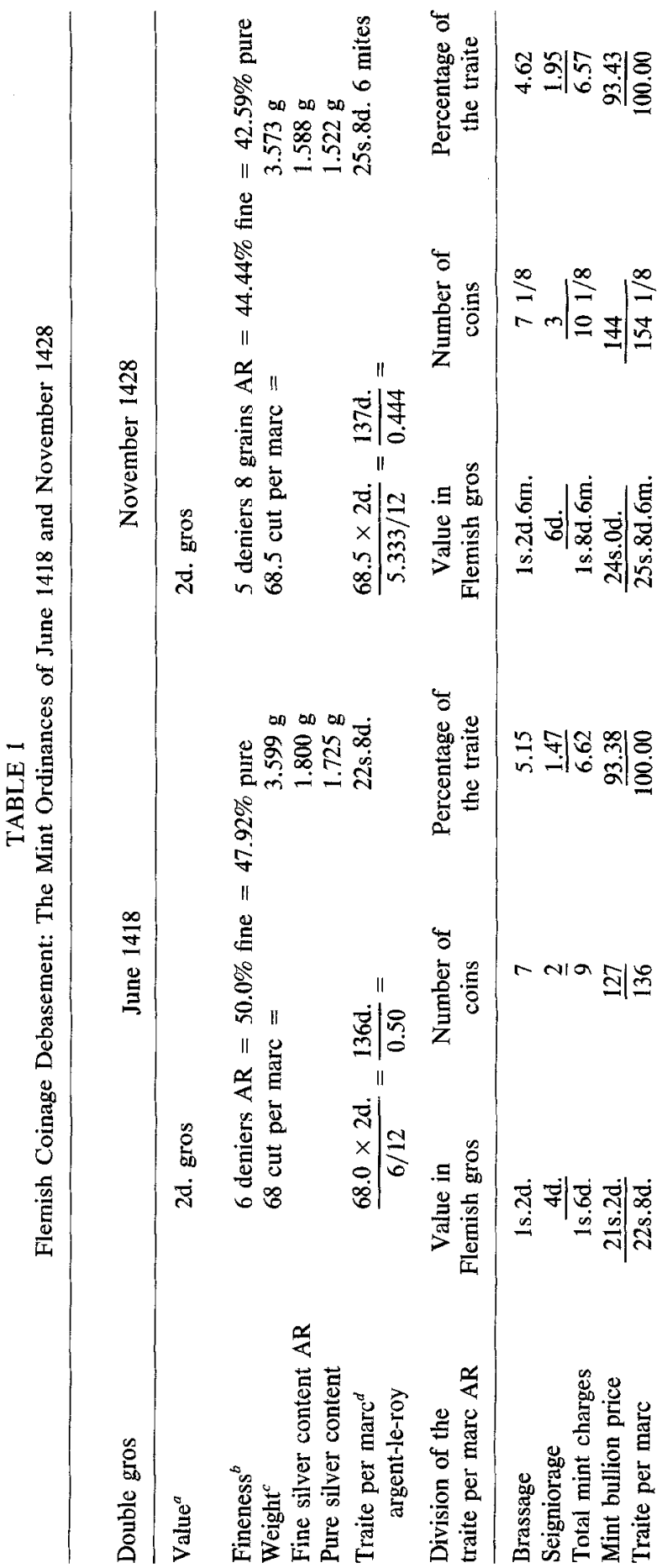




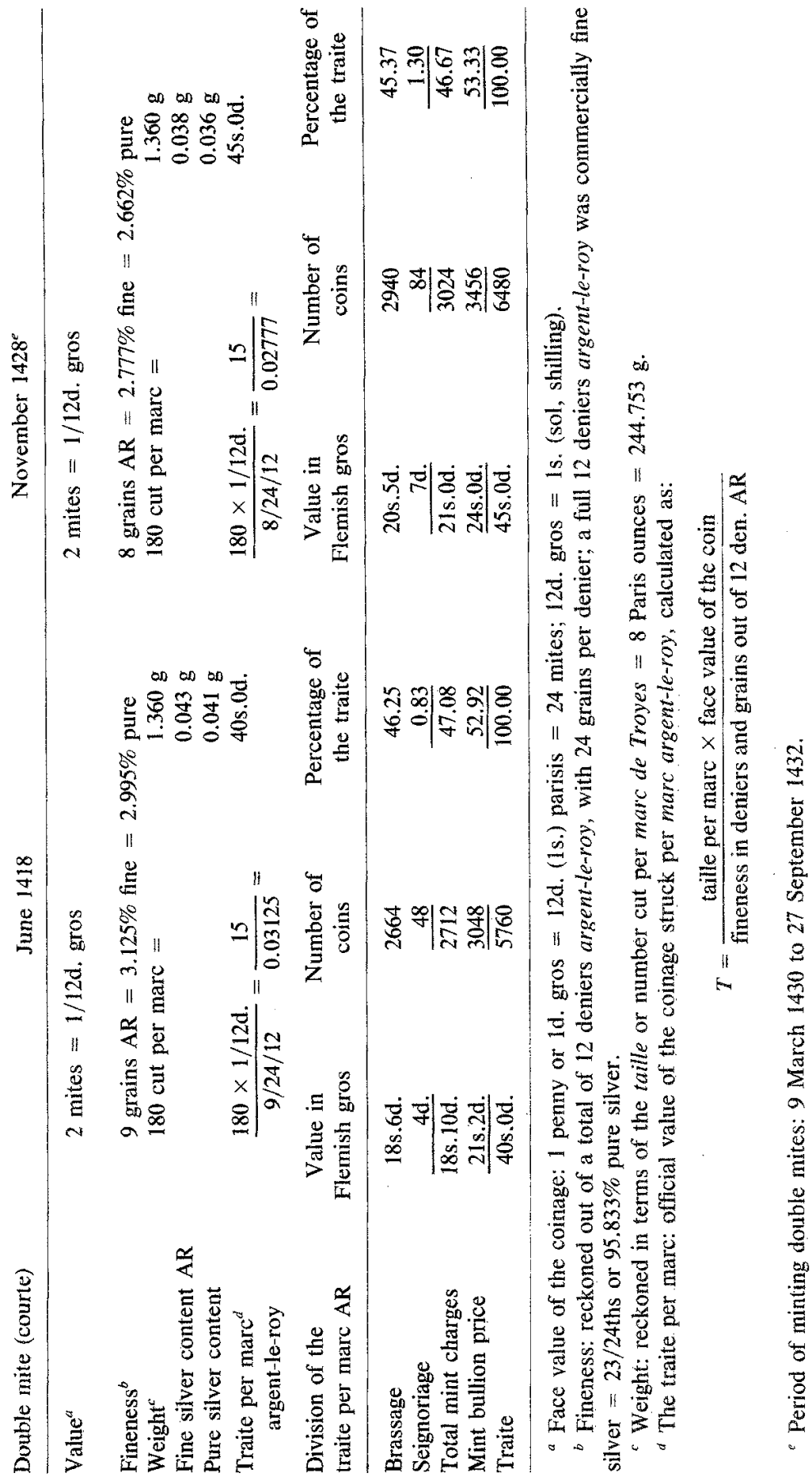


the traite: from $22.667 \mathrm{~s}$. (22s.8d.) to $25.6875 \mathrm{~s}$. $(25 \mathrm{~s} .8 \mathrm{~d} .6 \mathrm{~m}$.) per fine silver marc argent-le-roy.

As Table 1 further demonstrates, the principles of debasement, or of any coinage alteration, were the same for both large and small coin denominations. It is imperative to realize, second, that the Flemish petty coinage was an integral part of the silver money system. Fully convertible legal tender, it always contained some silver (until 1543), diminishing with debasements and increasing with renforcements (coinage reforms), more or less proportionally with changes in other silver coins, according to officially prescribed monetary ordinances (Tables $1,3,5){ }^{6}$ Thus not included in this definition are any token coins: i.e., those base-metal jettons of tin, pewter, lead, or copper, containing no precious metal, issued by the Church, other charitable organizations, or even individuals, as unofficial coins, invalid for taxes or official payments, that served only as private credit instruments.

The values assigned to genuine petty coins were some specified constant fractions of the silver penny or other "link money" that anchored the circulating coinage to the prevailing money-of-account. A modern synonym is thus fractional coinage. In medieval Flanders, the most common and very apt synonym was "black money"-monnaies noires, zwart geldbecause of the coins' very high base-metal contents. ${ }^{8}$ Their more formal names were mites: the single mite, worth $1 / 24$ of the silver penny gros or groot, and the double mite or courte, worth $1 / 12 \mathrm{~d}$. gros. ${ }^{9}$ These were the only petty coins struck in 14-century Flanders; but thereafter we may arbitrarily add the quarter-gros, the gigot or zeskin of 6 mites, first struck in that form in $1410 .^{10}$

${ }^{6}$ See sources cited in n. 4 above; and also nn. 5, 23, 41, and 50. Medieval canon lawyers were agreed that the amounts of petty coinage that had to be accepted in payment should be limited (Monroe, 1923, pp. 36, 96); but in Flanders no specific legal limitations were imposed.

${ }^{7}$ See Mitchiner and Skimner (1983, 1984); Grierson (1975, pp. 32-33, 162-171); Courtenay (1973); and Chalon (1847), on medieval accounting tokens, "jetons de calcul." See below p. 414; and n. 40 .

${ }^{8}$ The modern numismatic term is billon, a base coin with under $50 \%$ silver (Grierson, 1975 , p. 193). But that term can be very misleading, since its original medieval meaning was "bullion" (Munro, 1974); furthermore, many medieval coins with less than 50\% silver were not then considered "petty," while the English farthing (1/4d.), with $92.5 \%$ silver fineness, certainly was.

${ }^{9}$ In the older parisis money-of-account system, fixed in value at $1 / 12$ th of the gros system from $1318-1320$, the single mite was thus worth $1 / 2 \mathrm{~d}$. and the double mite, 1d.a penny. See the Appendix; Tables 4-6; and Ghyssens (1970, 1974), Dieudonne (1933).

${ }^{10}$ The quarter-gros struck from 1410 was silver rather than black money, with a fineness of $33.3 \%$ (falling to $16.7 \%$ by 1477). In December 1416, a 3-mite piece of $25 \%$ fineness was prescribed, but evidently not struck. See Deschamps de Pas (1861, pp. 223-225) and Tables 4-5. A quarter-gros ("petit blanc") had been briefly struck much earlier, in 13341336 (Gaillard, 1856, pp. 34-42). But, with a much higher silver content (85.4\% fine) and 
Third, one must realize that small silver and petty coins played a far greater role in medieval society than they do in today's economy. For most people, such coins were then certainly the principal means, for many the only means, of transacting retail trade, in buying and selling daily necessities. As Table 2 demonstrates, furthermore, the purchasing power of such coins was surprisingly high in late-medieval Flanders, because prices and wages were then so low. ${ }^{11}$ The expression "a penny for your thoughts" takes on new meaning when we find, ca. 1350, that a penny would then buy over $5 \mathrm{lb}$ of cheese or a gallon (4.8 $\mathrm{l}$ ) of wheat. Thus even the Flemish courte (double mite), with which one could have bought 6-7 oz of cheese in 1350 (or again in 1470), should not be too casually dismissed as "small change."

As Table 2 also demonstrates, the purchasing power of such silver coins changed often drastically over the 150 years that constitute the period chosen for this case study, from 1334-when the Flemish mint accounts commence-to 1484 , with the transition to the early-modern Habsburg regime. Those years are particularly significant in encompasșing the late-medieval economic contraction, or "Great Depression." For Flanders, the most urbanized, commercialized, industrialized, and monetized region in northern Europe, two particularly relevant, interrelated features of this economic contraction were widespread, chronic warfaremost notably the Hundred Years' War (1336-1453); and a growing scarcity of precious metals, especially from the 1370 s. Warfare was significant not only for its considerable economic dislocation but more for its financing by often drastic coinage debasements that in turn spawned veritable guerres monétaires, especially from the $1330 \mathrm{~s}$, in an international competition for bullion. Both the warfare itself and the accompanying debasements were highly inflationary, temporarily overpowering and reversing the prevailing deflationary forces of this era. The intervening periods of peace generally also resulted, in most continental countries, in coinage renforcements, monetary reforms, to remedy the inflationary damages from debasements-especially to the prince's feudal and tax revenues, which were usually fixed in money-of-account terms. Since creditors similarly suffered from debasements, the prince's continued access to credit was ultimately dependent also upon a renforcement. These reforms were themselves generally deflationary, by converting the current debased coins necessarily into a smaller quantity of strengthened coins. Flanders' monetary history can thus be portrayed as an oscillating pattern of debasement and reform, perhaps similar to Italy's (Cipolla, 1956): (A) 1334-

a much higher purchasing power (Table 2) -then worth $3 / 4$ of an English penny sterling, it did not then really qualify as petty coin.

"See also Cipolla (1956, pp. 33-34); Spengler (1966, pp. 205-208); and Murro (1975). 


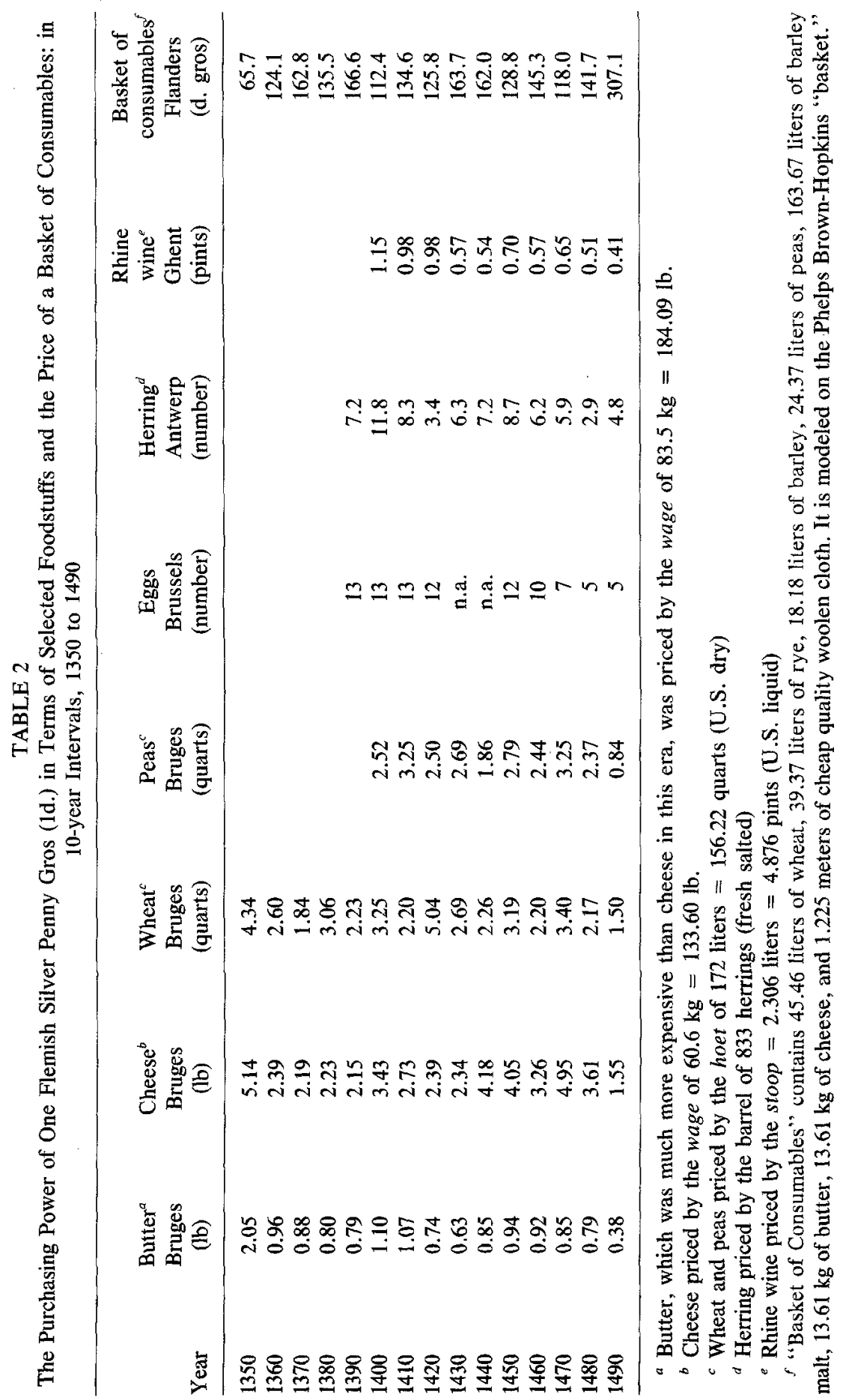


1389: warfare, debasements, with very large mint outputs, and severe inflation; (B) 1390-1416: relative peace, strong coinage, "bullion famine," and sharp deflation; (C) 1416-1433: extensive warfare, debasements, and inflation; (D) 1433-1474: relative peace, strong coinage, followed by "bullion famine," low mint outputs, and severe deflation; (E) 1474-1496: warfare, debasements, and severe inflation-with, as well, silver influxes from new Central European mines. ${ }^{12}$

During the inflationary periods $(\mathrm{A}, \mathrm{C}$, and $\mathrm{E})$, the relative demand for petty coins would presumably have diminished with the fall in their purchasing power; and correspondingly such demand would have risen with their higher purchasing power during the intervening deflationary periods ( $B$ and D), as suggested by Table 2 . The exact causes of these alternating inflations and deflations, the mixes of real (demographic) and monetary factors, are not our present concern. Nor can we establish here the role that such individual factors played in determining the aggregate supply of and demand for money, and the denominational composition of the gold, silver, and petty coinage circulations: all of which are reflected only imperfectly in the Flemish mint accounts.

From those mint accounts, the actual quantities of petty coin struck as mites and quarter-gros in Flanders from 1334 to 1484 , and the proportions of both the total silver bullion and total values of silver coinage minted in petty coin have been computed and presented in Table 3 . The physical composition and the minting costs of both mites and silver gros are compared over this 150 -year period in Tables 4 and 5 . Note first that the mint accounts record the striking of petty coins for only 61 or $40 \%$ of these years, with none struck at all from 1339 to 1375 . That particular 36-year lacuna may, however, be misleading. For the previous account of 1334-1338, while noting the coinage of 2637 marcs of noire monnoye, made no official reckoning of them "because My Lord [Count Louis de Nevers] exacts no seigniorage for them." 13 Since the real purpose of the accounts was to record the count's seigniorage revenues, subsequent mint-masters may have seen no need to list issues of mites so long as they remained seigniorage-free. At the same time, so long as they were seigniorage-free, the count had little financial incentive to require their coinage: especially Louis de Nevers' successor, Louis de Male (13461384), ill-famed for his highly profitable coinage debasements. Indeed mites do not appear in any monetary or mint ordinance during this 36-

${ }^{12}$ For elaboration and evidence, see Munro (1973, 1979a, 1979b, 1981, 1983a, 1983b, 1984); Day (1978); Spufford (1970); Miskimin (1963, 1964, 1975, 1983, 1984); Van der Wee (1963, Vol. 2, pp. 3-112, 285-316, 369-410); Mayhew (1974a, 1974b); Nef (1941, 1952); Braunstein (1983); Bordo (1986).

${ }^{13}$ Gaillard (1856, Doc. Nos. 17-21, pp. 31-58, with quote on p. 45). 


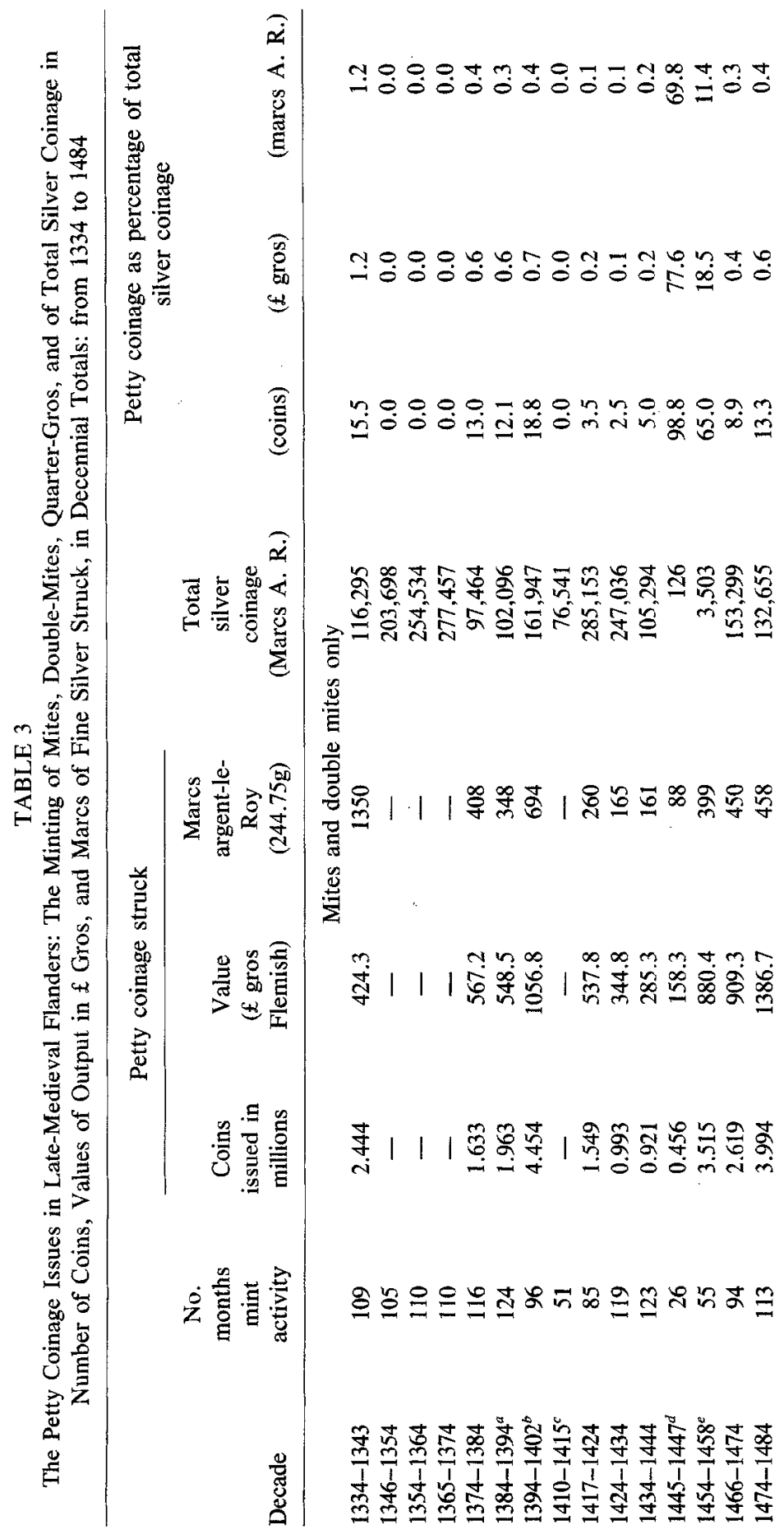




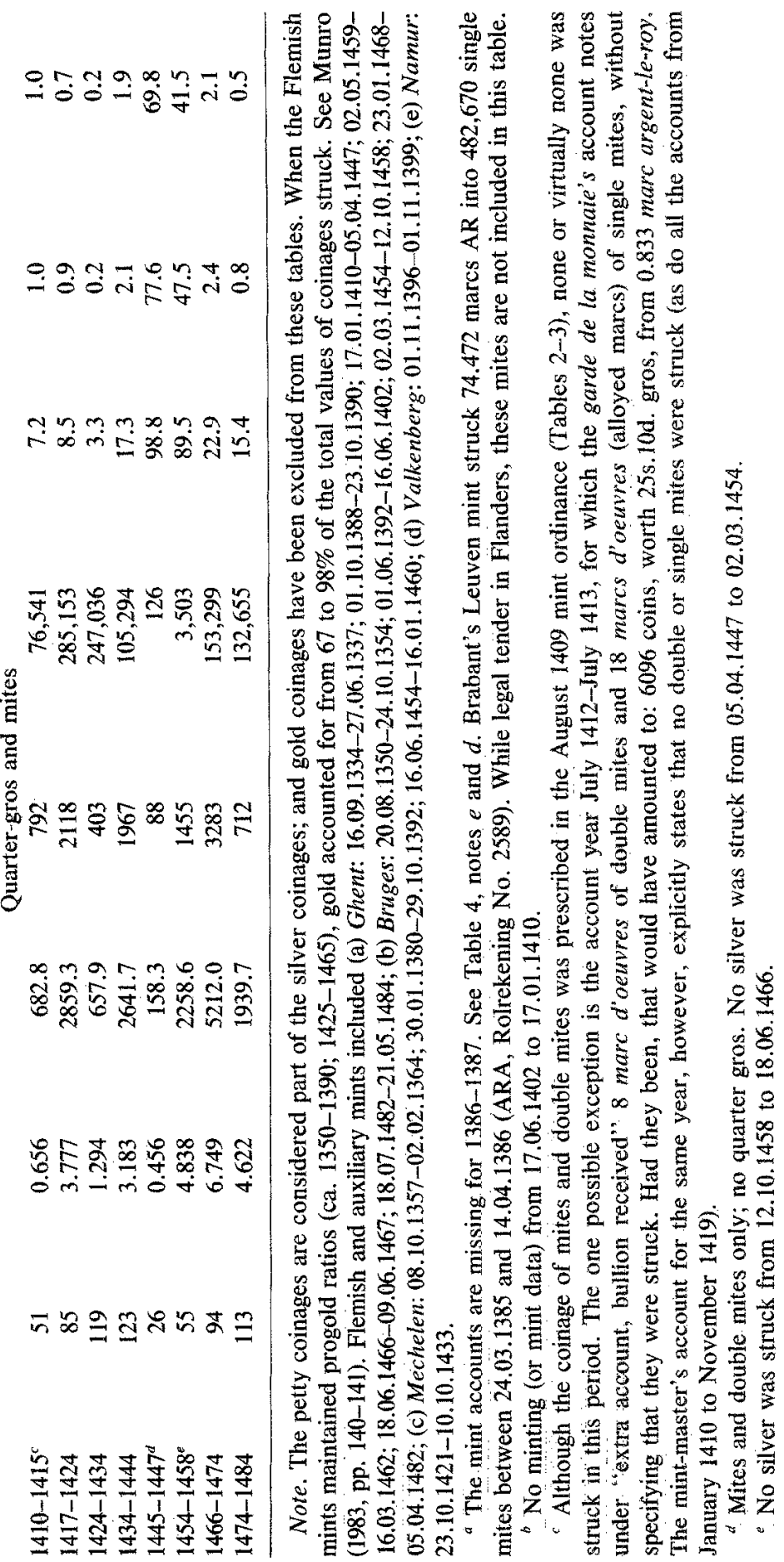




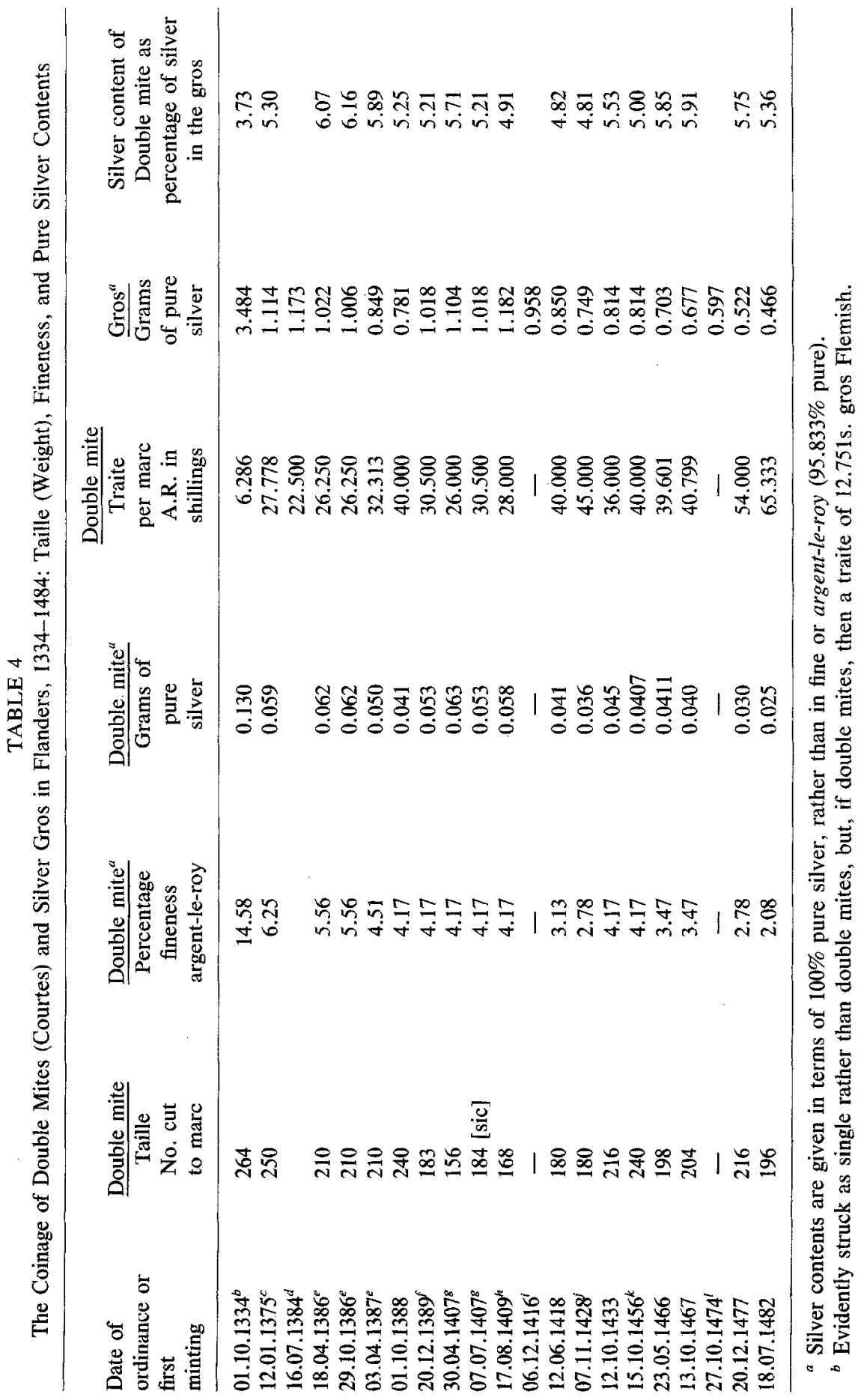




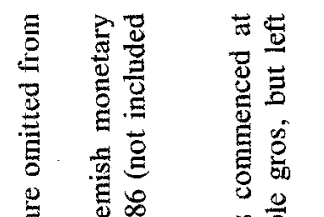

莺

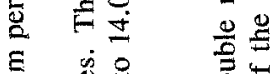

异象

$\Xi \quad \frac{\pi}{0} \quad$ b

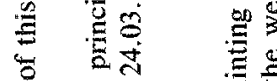

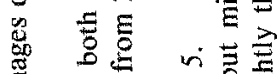

吾

$\Xi \stackrel{0}{\mathscr{N}}$ mi

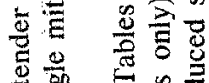

D

齐

¿ $8 \stackrel{0}{\mathrm{E}}$.

용 总造.

$\dot{\Delta}$
$\dot{B}$

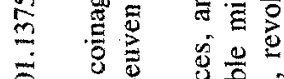

5. 0 욤

ㅎํㅇ

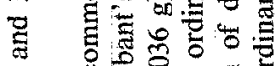

m 800000

ஊ 0 -

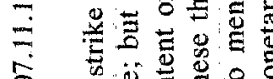

5 फ

ฐ

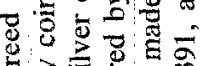

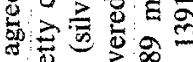

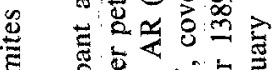

ह

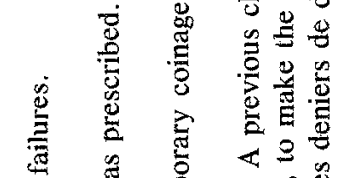

范

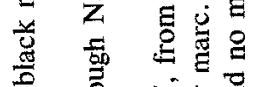

冚苔芯

吾

$\stackrel{0}{\Xi} \overline{0}$

¿ E $\Xi \pm$.

을

욜

恶导

$\stackrel{2}{\rightleftarrows}$

峞

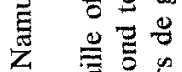

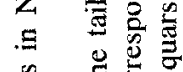

๘

- $\quad 8$ 퐁

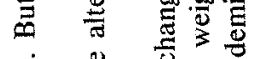

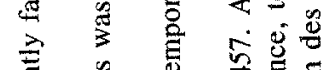

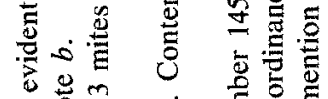

¿

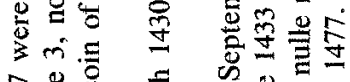

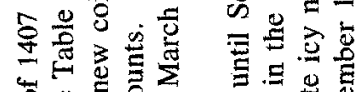

ธ。

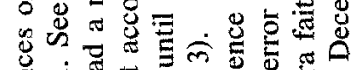

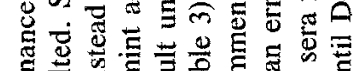

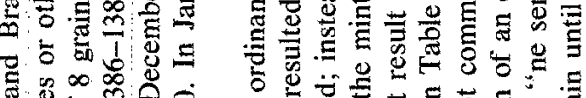

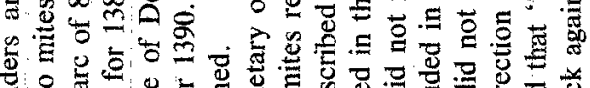

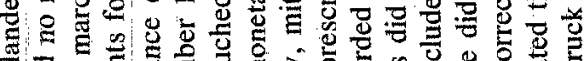

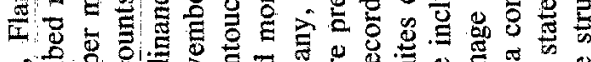

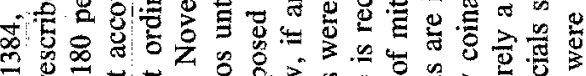
.

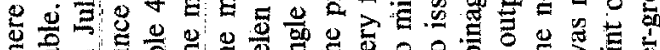
Eま

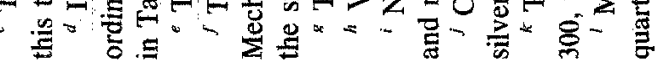




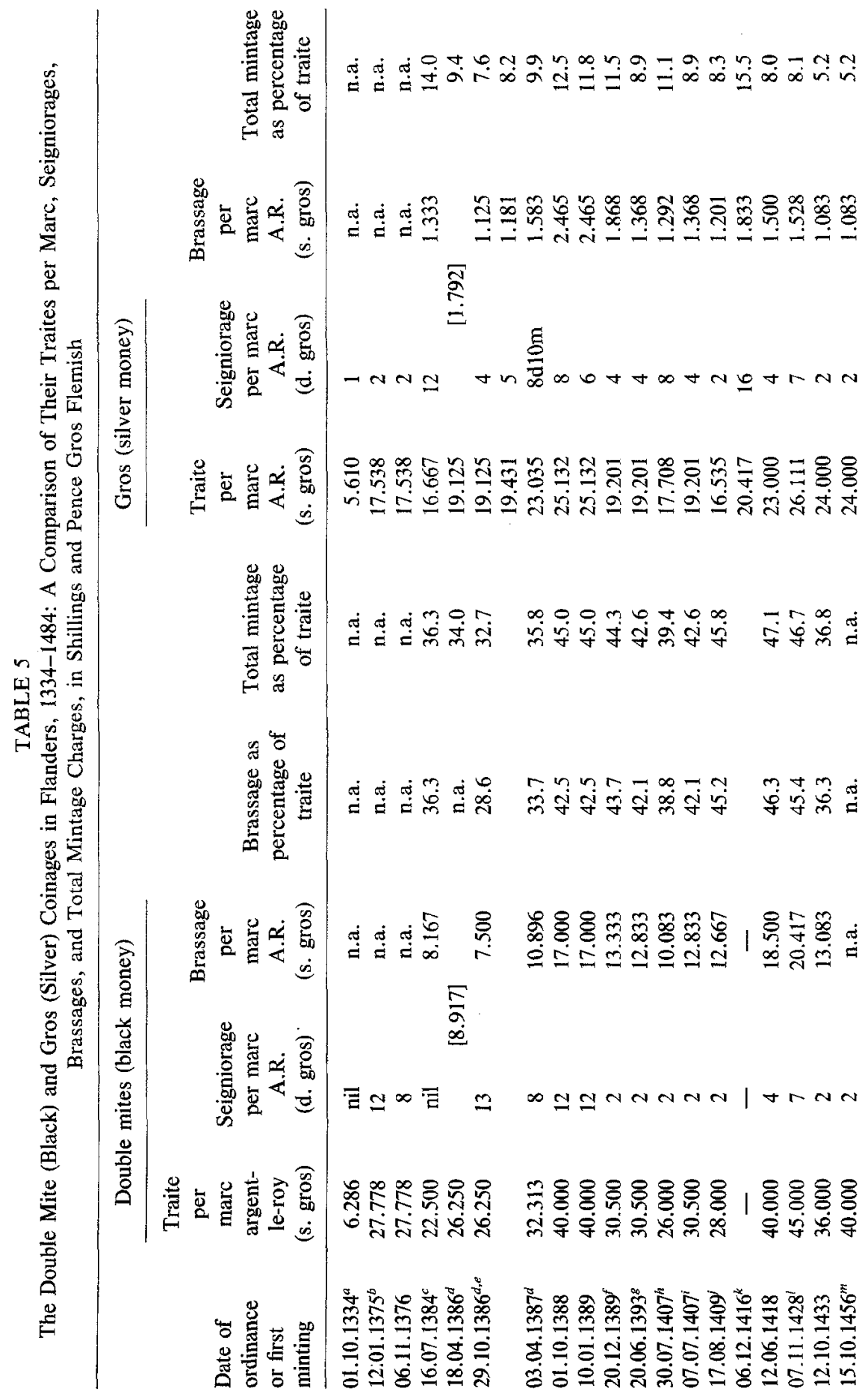




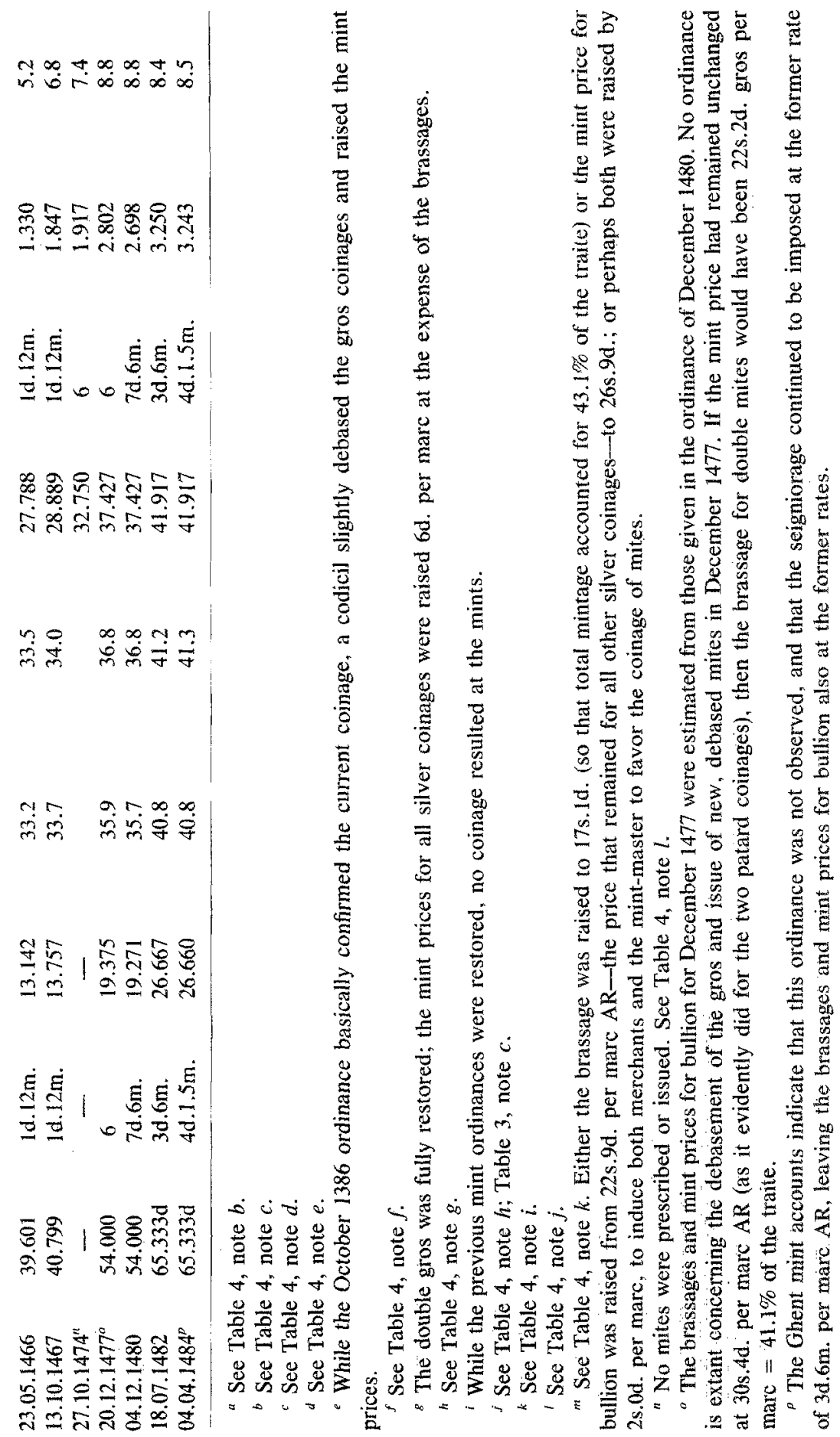


year period. ${ }^{14}$ When next recorded, in January 1375 , mites certainly were subject to seigniorage, which, thereafter, was always charged for their coinage (Table 5). There still ensued some other significant gaps in their issue: in 1378-1385, 1403-1418 (except possibly 1412-1413), 1448-1453, 1459-1465, and 1472-1477, the third and fourth of which reflect general mint inactivity (Tables 3 and 4).

But even apart from these lacunae, and even during the periods of intense mint activity, the Flemish petty coinage outputs were remarkably small for almost all of this 150-year period. We can see from Table 3 that, in terms of the proportion of total silver bullion minted, and even of the total money-of-account values of coinage output, amounts struck as petty coins were rarely more than $1 \%$, and generally under $1 \%$, until the mid-15th century. Furthermore, if we exclude those quarter-gros struck from 1410, and focus only on the true monnaies noires, the mites, then those proportions just specified drop dramatically to about $1 / 10$ th of $1 \%$ in some decades, with the significant exception again of the $1440 \mathrm{~s}$ and $1450 \mathrm{~s}$, to be analyzed later.

If, however, we consider the outputs of petty coinage in terms of the number of coins struck, we see that in four of the decades well over 4 million were struck; and in one (1466-1474), 6.8 million, accounting for $23 \%$ of total coins then issued. If the prince and his mint-masters had then been questioned about meeting their public responsibilities in providing adequate amounts of petty coinage, undoubtedly they would have pointed to such statistics, possibly with some justification. But most other observers, then and now, would likely endorse Philip Grierson's charge that their mints left the public desperately short of the very coins that most people required in paying for their daily necessities.

Grierson (1976, p. 113) and Spufford (1970, p. 44) have indeed provided a convincing explanation for that presumed scarcity, and one also given by Usher (1943, p. 198), Cipolla (1956, p. 28), and Spengler (1966, p. 209): that the costs of minting petty coins, with the crude technology of this era, were much too high to permit any profits for the mint-masters, who exercised a strong influence in constructing medieval monetary ordinances. Grierson's argument that "twelve times as much labour was involved in making 12 pennies as in making one shilling" has obvious merit. But it really applies in principle only to England's peculiar silver coinages, and only after June 1351, from which time all five coin de-

${ }^{14}$ For the mint policies of Count Louis de Male, see Van Werveke (1949a, 1949b); Blockmans (1979); Munro (1981). For the mint documents: Gaillard (1856, Doc. Nos. 28, $39,40,43,44,45,47,52,59,60,63,70,72,74$, pp. 74-156); and De Limburg-Stirum (1898, Doc. Nos. 848, 858-859, 913-916, 918-921, 924, 930, 946, 968, 970-971, pp. 121218). In the only numismatic literature known to me on Louis' petty coinage, Rouyer (1847, pp. 453-454) and Piot (1855b, p. 200) have both described just one extant, undated mite: evidently the same mite, from the obverse-reverse reproductions. Rouyer's weights for three examples ( 0.96 to $1.06 \mathrm{~g}$.) indicate that this mite was struck between 1375 and 1377 . 
nominations were struck of sterling fineness $(92.5 \%$, to 1542$)$, with proportionally equal weights. Consequently a Tower Pound of sterling silver produced identical traites (Tower Pound's money-of-account value by tale) for each and every coin denomination struck. Thus, so long as the English mint's bullion price remained the same for each, all denominations from farthings to groats (4d.) had to bear identical mintage fees per Tower Pound of sterling silver. ${ }^{15}$

Generally elsewhere in medieval Europe, however, and certainly in Flanders, all petty coins were deliberately struck to contain proportionally less silver than that contained in higher denomination gros coins, with some combination of inferior fineness and nonproportional weights, as shown in Tables 1, 3-5. Consequently these petty coins enjoyed a far higher traite per marc than that for the gros: higher values, with proportionally many more such petty coins struck per fine marc. Thus the mint could exact much higher brassage and seigniorage fees on petty coins, to cover fully the higher raw material and labor costs involved, while still allowing the mint-master a fair return. He might, however, have incurred a loss with a sudden rise in copper prices or wages-but only until the next coinage debasement.

We cannot, therefore, assume that the coinage of monnaies noires was necessarily everywhere always a losing proposition for the mint authorities. Lane and Mueller (1985, p. 202) have found, for example, that "Venice began to make very large profits on black money before the end of the fourteenth century." The real question to be asked instead is were the authorized brassage fees always sufficiently high to ensure that the mintmaster would indeed earn a profit $?^{16}$ The complete absence of monnaies noires (mites) in the Flemish mint outputs from April 1471 to December 1477 may be related to the very low brassage fees in that period of "strong money": amounting to just $34 \%$ of the traite, compared to the mean of $44 \%$ prevailing from 1388 to $1433 .{ }^{17}$ When the coinage of mites

${ }^{15}$ That mint policy with identical brassage and seigniorage charges for all silver coins seems to have been unique in late-medieval Europe. Brooke and Stokes (1929, especialiy pp. $40-42$ ) indicate that in 1547-1550 the Tower Mint did differentiate mintage fees by coin denomination. See also Blunt and Brand (1970), Crump and Johnson (1913), Challis (1978, pp. 305-325), and Munro (1983a).

${ }^{16}$ Spufford (1970, p. 42) has argued that coinage of mites provided "an insignificant profit margin, or even a loss, if made properly," citing in support the 1489 Ghent mint account and estimates of current copper prices. But the authorized brassage, in fact $\$ 37.17 .11$ d. gros per marc argent-le-roy, was only $32.7 \%$ of the double mite's traite of f116.0.5d per marc: proportionally the lowest such brassage on petty coinage so far in the 15 th century, well below the $40.8 \%$ of 1484 (Table 5). See also Usher (1943, pp. 196205).

${ }^{17}$ Furthermore, the Flemish monetary ordinance of October 1474 had pointedly if inexplicably refrained from prescribing the coinage of either mites or quarter-gros. No quartergros were struck either between April 1472 and December 1477. See Table 4, n. $l$; Tables 3, 5-6; Algemeen Rijksarchief (Belgium: hereafter ARA), Rekenkamer, Nos. 580 (fo. 100v). 
was resumed in the December 1477 debasement, the brassage was again raised, finally to $41 \%$ of the traite by 1482 (Tables 3-6). Occasionally the prince himself exacted too high a seigniorage at the direct expense of the mintmaster's brassage or of the merchants' bullion price, or both: as Tables 3-4 and 6 suggest for 1375-1376, 1386-1389, 1430-1432, and 1477-1482. But otherwise the seigniorage fees were either less than or no more than those imposed on the higher denomination coins (and nil in 1334-1338).

Obviously the monetary authorities had to ensure that they did not set the total of brassage and seigniorage fees so high, at the expense of the mint price for bullion, that they thereby encouraged merchants to deliver their bullion to foreign mints. But merchants would rarely have gone to foreign mints just to obtain petty coins, since their traveling and transactions costs would have been much too high in relation to the coins' value. Presumably, therefore, merchants would have been willing to accept domestic petty coins that had proportionally lower silver contents and higher mintage fees, so long as that higher cost did not exceed the petty coins' greater utility-than that for higher-valued coins-in effecting day to day transactions, in paying wages and in buying food, drink, and other daily necessities.

There is thus no justification for the argument that the cost of minting petty coins was universally too high for the prince, the mint-master, or the merchants. A more important criticism of the Grierson thesis, however, is that it fails to specify what amount of petty coinage constituted a "shortage," and under what circumstances. Admittedly, most historians will scoff, retorting that the figures presented here, with chronically less than $1 \%$ of mint outputs issued in petty coin, make such shortages selfevident. We must therefore find alternative explanations for these skewed mint statistics, while asking whether such small outputs of petty coins made them truly scarce in relation to (1) the demand for such coinage, and (2) the quantity that circulated domestically.

Indeed, in analyzing the composition of mint outputs, we must first consider the demand for petty coins on the part of those merchants and money-changers or bankers who supplied bullion to the mints. Insofar as such merchants were engaged in the regional and international commerce and finance of the medieval Low Countries, their demand presumably would have been strongly biased in favor of high-value coins, and would thus not reflect the more general, domestic public demand for coinage.

Consider in particular the different spheres of circulation for the various coinage denominations in the Low Countries. Flemish petty coins normally circulated just within Flanders itself; and, as Peter Spufford (1970, p.

and 18,107-18,111; Rouyer (1848, p. 430); Deschamps de Pas (1862, pp. 357-360); Spufford (1970, p. 180). 
42) has remarked, Burgundian coinage unification in 1433-1434 "did not extend below the quarter-groat," as each province continued to strike its own separate monnaies noires. But the higher-value silver gros, patards, and double patards (1d., 2d., and $4 \mathrm{~d}$.) had a much wider circulation: throughout the Low Countries and the Rhineland, and sometimes even further abroad. ${ }^{18}$ Indeed, occasionally the Flemish resorted to silver (coin and bullion) in financing international trade, when mint ratios so warranted, as may be demonstrated by the wool trade at England's continental staple of Calais. So long as England's Calais mint had favored gold, the Flemish purchased their English wools there with that metal, which accounted for most of its mint outputs. But when, from 1425, the Burgundian mint ratios were altered to favor gold even more strongly than the English, most wool payments were evidently made in silver at Calais, whose mint now "favored" that metal, indeed coining it almost exclusively from the later $1420 \mathrm{~s} .{ }^{19}$ Thus, in view of the medieval Low Countries' prominent role in the regional and international commerce of northern Europe, we should not be surprised to find that high-denomination silver coins normally accounted for a disproportionately high share of mint outputs in that metal. For the reasons just analyzed in the Calais trade, that proportion should have been higher, ceteris paribus, when the domestic Burgundian mints favored gold the most strongly, compared to neighboring mints (ca. 1425-1466).

Questions of the relative demand for various kinds of coinage cannot be divorced from those of coinage supply. Indeed one of the central considerations of medieval mint production was the continual replenishment of coinage stocks, which were far from being imperishable. They diminished from coin wear in circulation, from clipping and "sweating," from hoarding or conversion of precious metals into objets d"art, from piracy and shipwrecks, from careless losses, and from precious metal exports in financing international trade, diplomacy, papal taxation, and warfare. Such a listing, to be sure, groups together different types of metal losses: those that were permanent, and those that were temporary, or were offset by dishoarding and bullion imports; the loss of the coins themselves, temporary or permanent, and the loss of precious metal from the circulating coin. ${ }^{20}$

While each type of metal loss played its own role in determining the

${ }^{18}$ See Spufford (1964, 1970, pp. 55-129); Munro (1972, 1973, 1981, 1983a). One exception must be noted: Brabant's Brussels mint struck exact copies of Flemish double mites from 06:10.1435 to 31.10.1437. ARA, Rek., Reg. Nos. 17,987-17,988.

19 See Munro (1973, pp, 65-126, especially Table 1, p. 95; 1979), and for the later 14 th century, Munro (1981, especially pp. 102-107).

20 "Sweating": removing precious metal from coins by shaking them together in a leather bag. For various and differing views on the extent of medieval metal losses from all these various causes, see Patterson (1972), Mayhew (1974a), Grierson (1963, 1975, 1976); Munro (1979b, pp. 178 190; 1983a, pp. 97-112); Craig (1953, pp. xvi, 60); Miskimin (1964, 1983 , 1984, pp. 25-90); Johnson (1956, pp. xi-xii). See also n. 4 above and n. 22 below. 
need to replenish coin stocks, the last provides an important explanation for many recoinages, the nature of which in turn explains why petty coins normally constituted such a small share of total minting. Any general deterioration in the average quality of the circulating coinagefrom wear, tear, clipping, "sweating," and also from the introduction of foreign debased or underweight coins-inevitably reduced and finally eliminated the premium that coins necessarily commanded over bullion (see p. 392). The same result would occur if foreign mints or industrial markets raised their bullion price. In reaction to that loss of metal and coin premium, merchants would discount the entire silver coinage, good and bad alike, by bidding up bullion prices (even commodity prices), high enough that the domestic mint would no longer receive metal. Merchants would then cull any remaining good, high denomination coins and sell or export them as bullion. If the prince wished to revive his mints and coinage circulation, he had three choices: to restore the coinage to its former standard by a compulsory reminting at the public's expense; to do so at his own expense; or to effect a general debasement that more than matched the current inferior standard, while providing himself, the mint-master, and bullion merchants some profit. ${ }^{21}$

For obvious reasons, medieval princes generally selected the third option. To induce merchants and the public to surrender their silver coins voluntarily, the prince's mint necessarily had to offer a bullion price that exceeded at least the traite value per marc on the previous coin issues. Thus, in the Flemish silver debasement of November 1428, shown in Table 1 and discussed on p. 389, Duke Philip the Good increased the mint's bullion price for a marc argent-le-roy from $21 \mathrm{~s} .2 \mathrm{~d}$. to $24 \mathrm{~s} .0 \mathrm{~d}$.: from 127 to 144 double gros. To obtain the equivalent amount of fine silver in full-weight double gros of the previous standard set in June 1418 , a merchant would have had to supply only 136 such coins: i.e., $22 \mathrm{~s} .8 \mathrm{~d}$., the former traite value per marc, for a profit of 8 double gros or $16 \mathrm{~d}$. per marc. Thus, so long as such coins had not lost more than $5 \%$ of their silver from wear, tear, and clipping in circulation, merchants would have gained by surrendering them as bullion to the mint. ${ }^{22}$ But a marc argent-le-roy derived solely from double mites struck since 1418

${ }^{21}$ See Feavearyear (1963, pp. 10-20); Munro (1973, pp. 11-42); Bordo (1986).

${ }^{22}$ Full weight double gros of the 1418 standard should have contained, on average, 1.800 $\mathrm{g}$ fine silver (or $1.725 \mathrm{~g}$ pure silver: Table 1 ). If they had lost $5 \%$ of their silver contents, to contain on average only $1.710 \mathrm{~g}$ fine silver, then the merchant would have had to supply 143.13 such coins $(244.753 / 1.710)$, worth $23 \mathrm{~s} .10 \mathrm{~d} .6 \mathrm{~m}$. gros by tale in current circulation, to obtain the silver in a marc argent-le-roy. If the average silver loss had been $6 \%$, he would have required 144.65 old double gros $(244.753 / 1.692)$, worth $24 \mathrm{~s} .1 \mathrm{~d} .7 \mathrm{~m}$ by tale. For medieval England, Craig (1953, pp. xvi, 60) has estimated that circulating coins lost on average $0.2 \%$ of their silver per annum, i.e., $1.83 \%$ per decade; Patterson (1972, pp. 220 221) has given a much higher estimate of $1.0 \%$ loss per annum. See also Grierson (1963), whose calculations are closer to Craig's; and n. 20 above. 
would have required 5760 such coins, whose monetary value of 40 s. gros by tale ( $=$ traite per marc) was $66.7 \%$ greater than the new mint price for bullion. As can be readily determined from Tables 1, 4-5, no profitseeking merchant would have ever voluntarily surrendered mites as bullion to the mints during any debasement in late-medieval Flanders, because the mint's bullion price per fine marc was always less than the previously assigned traite value for such petty coins. For most debasements, merchants delivering other small coin (quarter-gros, demi-gros) as bullion would have rarely broken even, and only if such coins had been full weight, a most unlikely condition in view of their presumably high velocity. Thus one may doubt that even the most rigorously enforced recoinage would have produced much petty coin for reminting.

For that very reason indeed, princes and their mint-masters may have preferred to limit the proportion of scarce bullion minted into such coins: insofar as they anticipated that few petty coins would ever return for subsequent debasements, and thus as a source of mint profit. The mintmasters would hardly have welcomed them for recycling, moreover, with the high cost of extracting so little silver from them. But there is no documentary evidence citing such reasons, nor any such evidence that mints deliberately limited petty coin output to protect the premium and support high mintage fees, as later theorists argued..$^{23}$

If domestic reminting of petty coins was largely precluded by their minuscule silver contents, high brassage fees, and thus high traites, then similarly that same combination, and the aforementioned adverse value: weight ratio, usually also prevented the export of petty coins as bullion to foreign metal markets or mints, except in times of unusual scarcity. ${ }^{24}$ Consequently, losses from precious-metal exports, for whatever reason (or gains from imports), would necessarily have been largely in the form of high-value coins and bullion.

Only in two minor respects was the need to replenish stocks of petty coins possibly greater than that for high denomination coins: the greater likelihood of careless loss, with a small incentive for retrieval; and greater damage in circulation, so as to render the coins unacceptable in trade or taxes. Presumably petty coins had a much higher circulation velocity, to increase the likelihood of damage or careless losses; and certainly

${ }^{23}$ See Monroe (1923, pp. 96-98); Cipolla (1956, pp. 27-33); Spengler (1966, pp. 208$214)$ on 17th-century Italian writers. See also Cannan (1926, pp: 25-31), Usher (1943, pp. $193-236$ ), and nn, 5, 50. One may argue that the very high mintage fees for petty coinage, representing real costs for both bullion supplier and the mint, would have sufficiently limited the circulation of petty coins to ensure a high enough premium.

${ }^{24}$ See above pp. 404, 406; pp. 409, 411, and nn. 27, 34 below; and De Roover (1949, p. 82); Feavearyear (1963, p. 22); Munro (1973, pp. 29-30). Bantier (1951, p. 170) recounts a Montpellier report of ca. 1310 concerning the illicit export of 100,000 marcs of monnaies noires-but without documentation. 
their high copper contents rendered them much more susceptible to chemical erosion (Grierson, 1963, p. vii). At the same time, however, copper was more resistant than either silver or gold to purely physical erosion; and that protection may have outweighed the other disadvantages.

These arguments concerning relative coinage replenishment are put forward not to oppose but to complement the demand-based hypotheses, in explaining the small outputs of petty coin. They also reinforce the view that mint production statistics are a very imperfect reflection of actual coinage circulation. Nevertheless, even if the real need for continuous production of petty coin was much less than would be indicated by such statistics, many historians will undoubtedly still not fully exonerate the monetary authorities from Grierson's charge (p. 387) that they left "the public desperately short of small change."

Indeed not until the mid-15th century did the state show any concern about the petty coinage. But only in that era did a scarcity of petty coin become acute enough, evidently, to provoke public concern. In both England and the Low Countries, moreover, the monetary authorities did in fact respond directly with positive relief measures. So many years had passed since a general recoinage, especially in England (1411-1412), that the circulating coins had undoubtedly suffered considerable deterioration, with the consequences already indicated (pp. 405-406). Furthermore, the period ca. 1440-1470 marked the most severe phase of the late-medieval "bullion famine," of sharp monetary contraction, and of considerable deflation (Table 2). ${ }^{25}$ In such circumstances, as stressed earlier, the relative demand for petty coins would have risen with their increased purchasing power. At the same time, however, a bullion famine and a deteriorated coinage standard would have seriously curtailed the mints' ability to produce even petty coinage. Indeed coinage outputs across northern Europe were extremely meager during these years, and many mints, unable to cover their costs, were forced to close: the Flemish, in 1447-1453, and again in $1462-1466 .{ }^{26}$ Furthermore, when the Flemish mints were open, they maintained a strongly progold ratio (1425-1465), which would normally have discouraged the production of small silver and petty coins especially. Finally, the domestic Flemish circulation of petty coins may have been considerably reduced with the diversion of such coins to uses normally served by higher-value coins, including foreign trade payments and hoarding; and hoarding may have increased in response to the current conditions of economic depression and uncertainty discussed below (p. 416). Spengler (1966, p. 213) has argued that such diversions might occur during periods of monetary scarcity, if

\footnotetext{
${ }^{25}$ See Day (1978); Spufford (1970, pp. 118-21); Munro (1979a, 1979b, 1983a, 1983b, 1984); Miskimin (1983, 1984, 1985); Mayhew (1974b); Bordo (1986).

${ }^{26}$ Spufford (1970, pp. 116-121; also on the closure of German mints); Munro (1973, pp. 155-162; 1983a); Miskimin (1984, pp. 30-53, 127-190; 1985, for the French mints).
} 
petty coins could be substituted for high-value coins. In fact for these very years of "bullion famine" we have evidence for both the export of monnaies noires (to northern France in 1457-1459) and their deposit in coin hoards (in Liège and Brussels, 1465). ${ }^{27}$

Even in England, despite the current prosilver mint ratios there, silver coinage outputs in the 1440 s had fallen to their lowest ebb since the beginning of the century, during another bullion famine: with an annual average of just $250.6 \mathrm{~kg}$ silver $=1,068.8$ fine marcs. In the 1445 Parliament, a Commons petitioner complained about the "grete defaute" of silver among the poor. The Crown responded by requiring the Tower Mint to increase by $10 \%$ the number of halfpennies and farthings struck from the sterling silver pound, while leaving pennies untouched. ${ }^{28}$

In Flanders, the prince's official response was similar but came later, despite an even greater silver shortage. In the 1440 s, the Flemish mints were coining an annual average of just 510.8 marcs $(119.8 \mathrm{~kg})$ of fine silver: less than half the English output, and a very drastic drop from the high silver outputs that had followed the Burgundian monetary unification-reform of $1433-1434 .^{29}$ It is thus all the more striking to find that, in the 28 months from January 1445 to April 1447 (after which silver outputs temporarily ceased), monnaies noires accounted for $70 \%$ of the silver bullion minted and $99 \%$ of the total number of coins struck. Then in January 1454, a minor gold debasement succeeded in reactivating the Flemish mints, so that in just over 4 years they struck some 3503 fine silver marcs $(821.7 \mathrm{~kg})$, along with new gold. ${ }^{30}$ Of that, 1455 marcs were struck in petty coins: 399 marcs in mites, the rest in quarter-gros, accounting for $42 \%$ of total silver bullion and $90 \%$ of the total number of coins issued. If one objects that such proportions are impressive only because total outputs were then so small, consider and compare the average annual outputs of monnaies noires (mites) during years of active minting in the three decades concerned, following the Burgundian monetary reform: (a) in 1434-1444: $£ 27.95$ gros--just $0.15 \%$ of the bullion coined!; (b) in

${ }^{27}$ See Spengler (1966, pp. 212-213), For the Burgundian mites (and counterfeits thereof), Rouyer (1848; pp. 423-429), Deschamps de Pas (1866, pp. 200-206): reports of French officials on confiscations of mites at Boulogne; for the coin hoards, see Tourneur (1928), and n. 34 below. See also pp. 405,407 above.

${ }^{28}$ From February 1445 to October 1447 only, the London Tower Mint struck both halfpennies. and farthings at 33s. instead of 30s. per Tower Pound of sterling silver 1349.91 g): i.e., 792 halfpence or 1584 farthings per $\mathrm{tb}$, instead of 720 halfpence or 1440 farthings, thus reducing these coins' weight by $9.1 \%=10.0 \%$ increase in their traite per Pound (sce p. 389). G. B. Parliament (1777, Vol. 6, pp. 108-109, No. 36); Munro (1973, pp. 128-131); Brooke and Stokes (1929).

${ }^{29}$ See Table 3; Munro (1973, pp. 98-103; 1983, pp. 112-146); Van Gelder and Hoc (1960, pp. 9-12): Spufford (1970, pp. 4-6, 180-93).

${ }^{30}$ Munro (1973, pp. 149-150, 210); Spufford (1970, pp. 31-37); Van Gelder and Hoc (1960, pp. 12-16). 
1445-1447: $£ 75.23$ gros; and (c) in 1454-1458: $£ 190.93$ gros-almost seven times as much as in 1434-1444. From the mid-1440s, the Flemish mints had evidently been encouraged if not directly ordered to divert more of the silver bullion into monnaies noires.

At that time, Duke Philip the Good was unable to adopt any more effective remedy, because of his promise to the provincial Estates in 1433-1434 not to alter the coinage for at least 20 years. But finally, on 15 October 1456, after his promise had expired, the Flemish monetary authorities issued an ordinance that was almost an exact copy of England's 1445 edict. It instructed the Bruges mint to increase by $11.1 \%$ the number of double and single mites struck per fine marc, by means of a $10 \%$ reduction in their weight, while maintaining the former 1433-1434 standards for all other silver coins. The Bruges mint, however, did not commence issuing the new mites until September 1457, after receiving further instructions on 31 August "to supply the poor people with monnoye noire." 31 Then, just over a year later, on 12 October 1458, the Bruges mint closed. No more silver was struck for almost 8 years; a few gold coins were struck at Mechelen and Ghent until March 1462, when all Burgundian mints finally shut down (Table 3).

According to Peter Spufford (1970), significant quantities of counterfeit monnaies noires, very base imitations of Burgundian mites, were then circulating in the southern Low Countries. In his view, the offending mints in various petty seigniories along the eastern frontiers found it profitable to strike such monnaies noires, while Burgundian mints did not, by reducing the silver contents in their imitations. ${ }^{32}$ Given the small amount of silver in Burgundian monnaies noires, then just $4.2 \%$ fine (Table 4), one wonders whether there was any real difference in profitability. Nevertheless this was still a period governed by the 1433-1434 reform principle of "sound money," which had in fact required a $25 \%$ increase in the mites' silver contents, as well as no coinage alterations before 1454. Perhaps the 1457 weight reduction, therefore, was also designed to curb competition from those eastern seigniorial mints.

${ }^{31}$ Ordinance of 15 October 1456 given in the Bruges mint account of September 1457October 1458: ARA, Rek., No. 18,105. See also Deschamps de Pas (1862, pp. 123-124), Rouyer (1848, pp. 422-423); and also Spufford (1970, p. 42, n. 1 and p. 201), citing other documents, in particular a mint official's statement (1447) that any change in the monnaies noires would be a violation of the duke's promise not to alter the coinage; and also noting similar issues of new monnaies noires in Brabant and Holland. Whether the mint increased its silver bullion price for the coinage of mites is not certain. See Table 5, note $m$; and also Spufford (1966a), Munro (1973, p. 102); for the October 1433 ordinance, Deschamps de Pas (1861, pp. 473-475).

${ }^{32}$ The mints of Gerdigen, Grote Brogel, Reckheim, Rummen, Elsloo, Kessenich, and Kinroi, in the Limburg-Liège-Rhineland region. See Spufford (1970, pp. 44-46, 200-202, Appendix IV); and also Meert (1970); Rouyer (1848, pp. 423-429); Piot (1842, 1855a, 1855b, 1856a, 1856b); Tourneur (1928). 
This black-money influx may have been just a temporary phenomenon explained by the current circumstances. For no such coins, or any coins below the double gros, were listed in a Brabantine mint report of December 1430, which condemned the local circulation of counterfeit coins struck by several of the same seigniories (Rummen, Reckheim, and also Arnhem, Liège). ${ }^{33}$ Since their mint accounts have not survived, these seigniorial black-money issues cannot be quantified; their significance can be gleaned only from the analysis of two very rare hoards composed almost entirely of such coins buried in Liège and Brussels ca. 1465. Most medieval hoards contain no monnaies noires; indeed for that reason and many others, hoards are an unreliable measure of coin circulation. ${ }^{34}$

In this era of bullion scarcity, the Burgundian mints remained closed again for over 4 years, until reactivated by the general, if minor, debasement and recoinage of both gold and silver in June 1466. The Burgundian monetary ordinance of 23 May 1466 effecting that debasement, and a reversion to a prosilver policy, was the first such decree to recognize a direct public interest in the coinage composition, particularly in terms of the public's need for petty coinage. Perhaps to some considerable extent such concern reflects the fact that Duke Philip the Good, responding to English and other foreign debasements in 1464-1465, had to seek agreement from the town-dominated provincial Estates for his own defensive debasement. Those Estates had long claimed a share in the governance of the Burgundian principalities; and seven meetings were required, from January 1465 to May 1466, before the monetary ordinance could be officially promulgated. In such circumstances, we have no grounds for dismissing its preamble as mere hypocrisy ${ }^{35}$ :

that one of the principal points of all good policies on which public well-being, as much for us as for the people, is founded is to have and maintain good money, sound and durable, in both gold and silver coin.

This ordinance, after determining the fineness, weights, and official values of the new coins, gold and silver, then made some stipulations about the composition of the coinage, "so that everyone may be provided with all denominations of gold and silver coins, according to each one's requirements and necessity." For each gold marc minted, the mint-master

${ }_{33}$ ARA, Rek., carton 65:2; Munro (1972, 1973, pp. 212-214). See n. 27.

${ }^{34}$ Spufford (1970, pp. 200-213, with Appendix V on Coin-Hoards); Piot (1842, 1855a); Tourneur (1928); Van Keymeulen (1973). Deschamps de Pas (1866, pp. 200-206) believes, however, that the counterfeit mites confiscated at Boulogne in 1458-1459 (see n. 27) were probably struck by Jeanne de Wesemael of Rummen. On coin hoards generally, see Grierson (1975, pp. 124-139; 1976, pp. 106-109; 1979, essays Nos. xxi and xxii).

${ }^{35}$ ARA, Rek., Reg. No. 133 (fo. 174v-179v); see also Munro (1973, pp. 150-179); Spufford (1970, pp. 44-46). Late-medieval Spain evidently also required a similar proportional striking of the silver coinage: Cipolla $(1956$, p. 31); Usher (1943, pp. 197-198). 
was to strike 100 silver marcs; and for every 100 silver marcs minted in double gros or patards (2d.), he was to strike 10 marcs in double patards (4d.), 2 marcs in single gros (1d.), 1 marc in demi-gros, and 1/2 marc in quarter-gros. But this monetary ordinance is also significant for introducing both a new heavy silver coin, the double patard worth 4 d. gros, and, more importantly, a differential in the mint bullion prices favoring that new coin (and subsequently, the patard also): 26s.9d. per marc argent-le-roy, vs $26 \mathrm{~s} .4 \mathrm{~d}$. per marc for all other silver coinages.

Whether or not the Burgundian monetary authorities fully realized that this mint price differential contradicted the policy of promoting the petty coinages, state monetary policies had certainly changed, particularly with the provincial Estates' increasing demands for stronger controls over the Burgundian coinage. Peter Spufford (1966a, 1966b, 1970, pp. 147-163) has argued more generally that, because of the Estates' political successes in the late medieval Low Countries, "the doctrine that coinage belonged to the prince had given way to the doctrine that coinage belonged to the people." ${ }^{36}$ Indeed, at the very close of our period, in December 1480 and again in April 1484, the new Habsburg ruler, Archduke Maximilian, issued another coinage ordinance similar to that of 1466, "so that the poor people may find themselves sufficiently supplied with petite monnoie." That decree required an even greater proportion of the mint output, if still a small one, to be struck in lower denominations, as shown in Table $6 .^{37}$ One might still cavil, however, that Count Louis de Nevers (13221346) was far more public-spirited than any of his Burgundian or Habsburg successors, in minting monnaies noires free of seigniorage; and that Maximilian, at war with his Flemish towns (1482-1494), was as rapacious as any in exploiting the mints. ${ }^{38}$

Thus one may well doubt to what extent the mint-masters actually observed these public-spirited monetary ordinances, which, in effect, prevented them from fully meeting their own customers' demands for coin denominations. An analysis of the Flemish mint accounts following the ordinances of 1466,1480 , and 1484 , presented in Table 6 , provides a mixed verdict on the mints' compliance. Following the first, the mints

\footnotetext{
${ }^{36}$ See also Munro (1973); Blockmans (1973, 1974); Bordo (1986); and the influential 14thcentury treatise "De Moneta" by Nicholas Oresme, Chaps. 6 ("Thus money belongs to the community and to individuals") and 22 , in Johnson (1956, pp. 10-11, 35-37).

${ }^{37}$ The mints were ordered to strike, for every 100 fine silver marcs coined into patards, 50 marcs in single gros, 10 marcs in demi-gros, and 5 marcs in quarter-gros. Texts in the name of Maximilian's wife and son, Duchess Marie (December 1480) and Archduke Philip the Handsome (April 1484), are reproduced in Deschamps de Pas (1862, pp. 465-470; 1869, p. $99 ; 1874$, p. 14 ), who is obviously incorrect in stating that this is the first ordinance requiring such a proportional striking of coins. See also Spufford $(1970$, p. 45); Grierson (1975, p. 97).

${ }^{38}$ See in particular Spufford (1970, pp. 141-146, 158-163); Blockmans (1973, pp. 128133; 1974); Van Uytven (1975).
} 


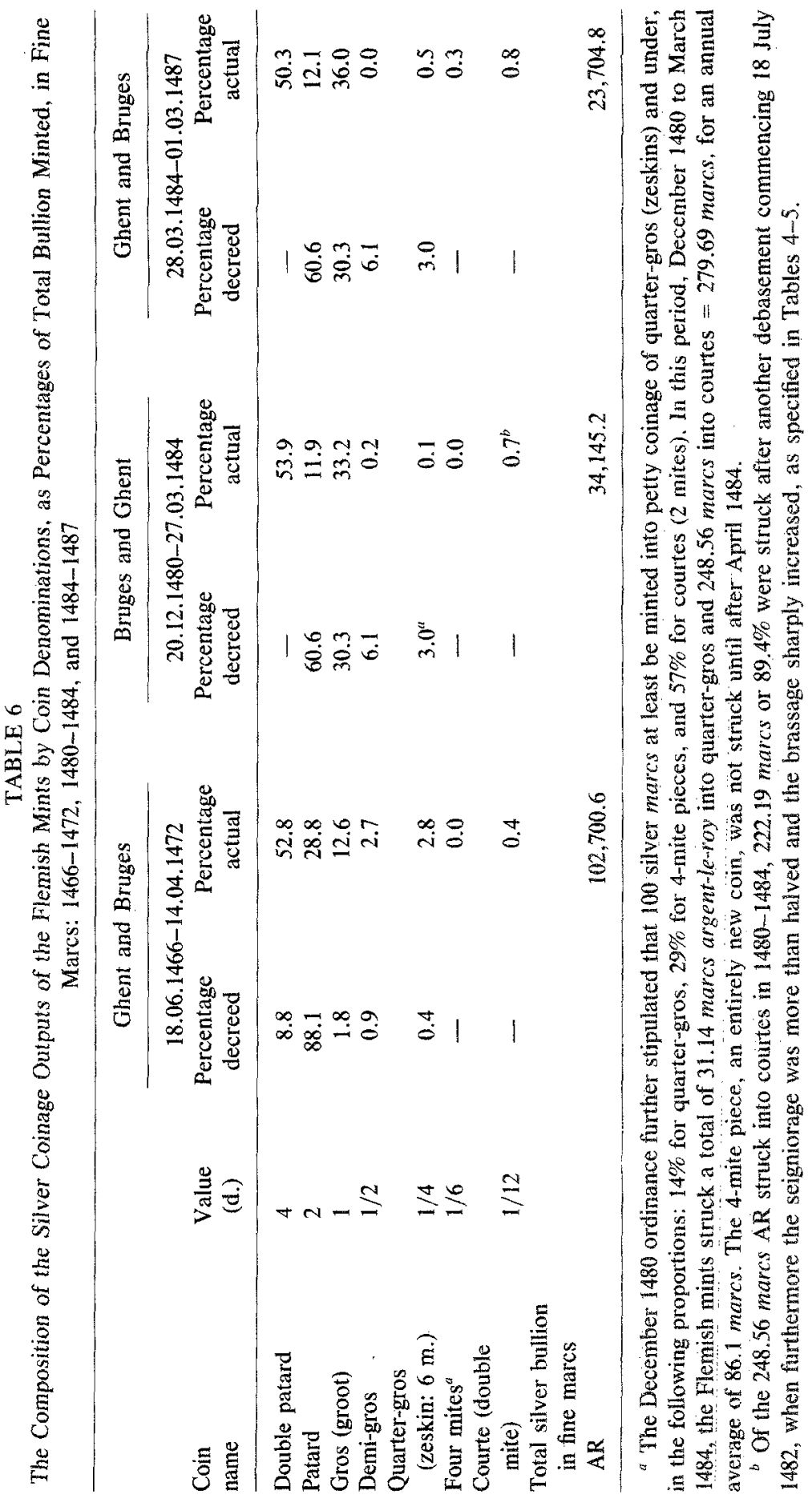


more than met their obligations, at least for denominations below the double gros: such coins accounted for $18.5 \%$ of the bullion coined, instead of the stipulated 3.1\%. As noted earlier (p. 402 and Table 3), the decade following 1466 marked by far the largest issue of petty coinage in this entire 150-year period. But far less bullion was struck in those lesser denominations, except for the single gros, in the years following the next two ordinances. ${ }^{39}$ Those years were highly inflationary ones of civil war and debasement during which the relative demand for petty coins presumably declined.

Those historians already convinced by all the mint-output and monetary data, and certainly those still convinced by the Grierson thesis, will be impatient with the concluding contention that the case for a chronic "scarcity" of petty coins has not been proven. To say that such scarcity or shortage characterized the economy of late-medieval Flanders is equivalent to stating that there persisted an excess demand for petty coins at current prices and incomes. While such conditions may have been temporarily true, especially in the mid-15th century, it is difficult to believe that such excess demand was not finally dissipated or satisfied. We lack the evidence to state precisely how-apart from the aforementioned state intervention to have more petty coins minted; but several hypotheses may be advanced, with qualifications.

First, some of that demand was undoubtedly satistied by the resort to foreign counterfeits of Burgundian-Flemish monnaies noires-the very ones discussed above (p. 410)-and also to token coins, though to a much lesser extent. Mitchiner and Skinner $(1983,1984)$, in their exhaustive studies of medieval token coins, stress that they "should not really be conceived as a straight monetary substitute," that they "did not compete with authorised coinage either in England or on the Continent," and that their scope was severely restricted. ${ }^{40}$ Not until 1543 did the Habsburg authorities in the Low Countries adopt the expedient of issuing their own fiat token coinage, as purely copper double mites. ${ }^{41}$

Second, another, at least partial, resolution of the coinage scarcity problem may have come from an increased resort to credit. ${ }^{42}$ Van der

${ }^{39}$ See in particular note $b$ in Table 6, concerning the change in mintage fees in 1482. A similar exercise, for 1466-1467 and 1480-1482, with less charitable conclusions, is given in Spufford (1970, pp. 44-45).

${ }^{40}$ And also, the token coin "is better thought of as being a chit-for-service." (Mitchiner and Skinner, 1983, p. 29). Most such coins were issued by the Church for alms-giving and other charitable purposes. See n. 7 above.

${ }^{41}$ See Van Gelder and Hoc (1960, p. 75).

${ }^{42}$ See in particular for the Low Countries, De Roover (1948, especially pp. 48-75, 99 219; 1949, pp. 115-117); Van der Wee (1963, Vol. 2, pp. 337-353; 1977, pp. 300-376); and the classic if outdated Bigwood (1921-1922, 2 vols., especially Vol. 1, pp. 235-255, 507520). For England, see especially Postan (1928, 1930); Holden (1955, pp. 4-84); Munro (1979b, pp. 213-215). 
Wee $(1963,1977)$ has contended that in the Low Countries pawnbroking became a common expedient "to offset coin shortages" for consumption transactions from the mid-14th century; and that from the 15th century the retail trades came to utilize sales credit in the form of "tallies" (notched sticks) or current-account debits, some involving partial settlements in kind ("barter-clearances") ${ }^{43}$ Nevertheless we must not exaggerate the current role of credit, most forms of which still remained tied directly or indirectly to precious metals. Peter Spufford (1986, p. xxx) contends that even in 15th-century Venice and Bruges, Europe's two leading commercial centres, only $10 \%$ of adult males had bank accounts, and that "the vast majority of transactions . . . were still carried out with actual metallic coin."

In the 15 th century, furthermore, especially from the $1420 \mathrm{~s}$, the governments of both England and the Low Countries imposed many severe restrictions on credit-apart from the traditional usury prohibitions-as part of misguided policies to promote bullion influxes and protect their coinages. In the latter, Burgundian officials had accused bankers ("taffletiers") of exporting bullion and importing fraudulent coin; and as part of the 1433-1434 monetary reform, the government prohibited depositbanking, a ban confirmed in 1467, 1480, and 1489. Pawnbroking was also restricted, in 1451 and more strongly in 1473 and 1477 . Even municipal authorities imposed similar restrictions, in Antwerp and Lier: forbidding innkeepers to sell on credit $(1442,1457){ }^{44}$

Such credit bans were, to be sure, difficult to enforce, especially in retail transactions. But Van der Wee $(1963,1977)$ and De Roover (1948) are agreed that deposit-banking had virtually disappeared from the Low Countries by the later 15th century; and Van der Wee contends further that "pawnbroking decayed from the second half of the fifteenth century onwards," while current-account tallies did not become truly widespread until the 16th century. Such credit restrictions may also help explain the high real interest rates of the deflationary mid-15th century: $20 \%$ on short-term public loans in Flanders, and $43.3 \%$ in pawnbroking ( $2 \mathrm{~d}$. per $£$ per week). In turn, public protests against high interest rates led to more state restrictions on credit. $^{45}$

${ }^{43}$ Van der Wee (1963, Vol. 2, pp. 333-340; and 1977, pp. 300-304). Aiso used, but more for commercial and investment purposes, werc (a) the letter-obligatory (cédule obligatoire, a form of promissory note), for which partial settlements were also made by "barter clearances"; and (b) annuity contracts, especially the bail a rente, the sale of real estate for hereditary annual payments. Both were transferable, assignable to third parties.

4. De Roover (1948, pp. 130, 338-342); Van der Wee (1963, Vol. 2, pp. 333-340, 355358; and also 1977, pp. 302-303); and Munro (1973, Chaps. 4, 6; 1979b, pp. 194-196. 204208; Appendices D-E).

45 De Roover (1948, p. 131-133; 339-341); Van der Wee (1963, Vol. 1, p. 526. Appendix 45-1; Vol. 2, pp. 105-109, 335, 355-358; and 1977, pp. 302, 362, Table 26). The Burgundian Great Charter of 1477 decreed that pawnbroking interest rates be cut in half. 
Deflation itself obviously brought some considerable relief to coin shortage in general, especially by the midcentury, in allowing each unit of coinage to effect transactions of greater real value; but the deflation, when achieved, did not fully resolve the problem of excess demand for petty-coins specifically. As argued earlier, the monetary and other economic conditions of this era, particularly the progold mint ratio, periodic mint closures, and the "Spengler effect" (p. 408), may have made petty coins a smaller proportion of the domestic money supply, before the midcentury state interventions, and thus even scarcer in relation to the demand for coinage. Furthermore the relationship between money supplies and prices was only indirect, particularly because of considerable institutional wage and price "stickiness": prices did not fall immediately, nor did they fall proportionally, in unison; some indeed remained stable. ${ }^{46}$ Furthermore, as indicated earlier, the mid-15th century was a period of considerable economic depression in the Low Countries, with a fall in production and commercial transactions, especially severe in the textile and agrarian sectors of the economy, which suffered extensive impoverishment. ${ }^{47}$ It cannot be determined, however, whether the "bullion famine" (and the accompanying deflation) contributed directly or indirectly to that depression or merely reflected it; nor can it be determined whether any petty coin scarcity restricted the volume of retail transactions.

Undoubtedly the true resolution to any problem of "excess demand" or petty-coin shortage in this era, one of limited scope and duration, came subsequently, from the latter 1460s: from the South German silver influxes, as part of the economic recovery based on the expanding Brabant Fairs, though disturbed by anti-Habsburg revolts and civil wars; and from the inflationary coinage debasements spawned by those wars. ${ }^{48}$

Finally, one must face the limitations of these beguiling mint data and admit that the quantity of petty coin "sufficient" for the economy of the late-medieval Low Countries cannot really be specified, ${ }^{49}$ while emphasizing a principal conclusion from this study: that the Flemish mint accounts grossly understate the amounts of petty coin in domestic circulation. At the same time, there is certainly no evidence that the Low

${ }^{46}$ See both the composite weighted price index for Flanders and its component series for farinaceous, drink, dairy, and industrial products in Munro (1984, Table B-5, pp. 104$105)$; and also Table 2 above. The quinquennial composite price index $(1450-1474=100)$ fell from a high of 137.7 in $1435-1439$ to 120.6 in $1440-1444$, to 101.3 by $1450-1454$; then rose to 113.9 in $1455-1459$, falling thereafter to its nadir of 93.9 in 1460-1464, and recovering only to 96.0 in $1470-1474$.

${ }^{47}$ Van der Wee (1963, Vol. 1, pp. 457-474, for wages; Vol. 2, pp. 61-111; and 1978); Munro (1973, Chaps. 4-5; 1979a, 1983b, 1984).

${ }^{48}$ Van der Wee (1963, Vol. 2, pp. 73-88); Munro (1983a, 1984); Nef (1941); Van Uytven (1975).

${ }^{49}$ Compare with Spengler (1966, p. 201): "It is not possible to define the extent of a coin shortage with precision, since the indicators of both supply and demand are indirect." 
Countries were ever plagued by any "inflationary excess" quantities of petty coinage, especially not in the mid-15th century - when it accounted for the bulk of mint outputs. In most periods, the Flemish and subsequently the Burgundian monetary authorities evidently provided, if quite unintentionally, the essential requirements for a sound system of petty coinage, as recommended by later theorists: coins struck with a commodity value much lower than the stipulated face value; convertibility of such coins with higher denomination silver coins; state monopoly on such coinage; and strictly limited issue of such coins. ${ }^{50}$

\section{APPENDIX: COINAGE}

1. The Flemish monetary system, its coinage and money-of-account, was originally based on the parisis system of northern France: with $£ 1$ (livre) $=20 \mathrm{~s}$. (sols) $=240 \mathrm{~d}$. (deniers), or current silver parisis pennies. From about 1318-1320, that was superseded in Flanders by the gros system, whose coin was originally based upon the French gros tournois (first struck in 1266), which ca. 1315-1320 was worth 15 d. tournois and $12 \mathrm{~d}$. parisis. By the 1340 s, the French and Flemish monetary systems had parted company fully and forever. The Flemish parisis system lost its own coins (except the mites) to become simply a money-of-account, subsidiary to and frozen in a permanent relationship with the gros system, whose silver penny had become the "link" money, anchor of the Flemish monetary system:

1 livre gros [pond groot] $=12$ livres parisis

1 livre gros $=20 \mathrm{~s}$. gros $=240 \mathrm{~d}$. gros

1s. (sol, schelling, shilling) gros $=12 \mathrm{~d}$. (deniers, penningen) gros

1d. gros $=3$ esterlins $[$ ingelschen, sterlings $]=24$ mites $=12 \mathrm{~d}$. or 1s. parisis.

2. Marc de Troyes was the mint weight unit of France and the Low Countries, consisting of 8 Paris onces $(=1 / 2$ of the Paris livre $)$, with a theoretical weight of $244.753 \mathrm{~g}$.

3. Argent-le-roy was the official standard of fineness for silver, reckoned in terms of 12 deniers, with 24 grains per denier; it was $23 / 24$ ths or $95.833 \%$ pure silver, vs. English sterling fineness of $92.5 \%$.

4. Tailleis, the number of coins to be cut or struck to the alloyed marc de Troyes (with a tolerance or remède of some specific number of coins per marc), indicating the theoretical weight of a coin.

5. Traite, akin to the French pied de la monnaie, is the total moneyof-account value, by tale, of the mint weight unit of fine metal (marc

${ }^{50}$ See Cipolla (1956, p. 27-29); Cannan (1926, pp. 25-31); Usher (1943, pp. 193--236); Montoe (1923, pp. 96-98); Spengler (1966, pp. 208-213); and nn. 5, 23 above. 
argent-le-roy, for silver), as struck into coins of the prescribed value, fineness, and weight (i.e., taille). Its calculation is

$$
\mathrm{T}=\frac{\text { taille }(\text { No. of coins per marc) } \times \text { official face value of coin }}{\text { percentage fineness (in deniers and grains argent-le-roy) }} .
$$

\section{SOURCES FOR THE TABLES}

\section{Mint and Monetary Statistics: Tables 1, 3-6}

(a) Ghent, Bruges, and Mechelen Mints, 1334-1384; Gaillard (1856, Vol. 2); Blockmans (1979, pp. 69-94); Van Werveke (1949a, 1949b); Munro (1981, 1983a).

(b) Ghent, Bruges, Mechelen, Valkenberg (Fauquemont), and Namur, 1384-1484: Algemeen Rijksarchief België, Rekenkamer (Archives Générales du Royaume, Chambre de Comptes), rolrekeningen Nos. 776-787 (Bruges, 1392-1402); Nos. 824-831 (Ghent, 1388-1390, 14101419); Nos. 2586-2587 (Valkenberg, 1396-1398); Nos. 2142-2143 and 2145-2146 (Mechelen, 1384-1385, 1390-1392); Registers Nos. 48,876-48,877 (Mechelen, 1390-1392); No. 580 (Ghent, 1419-1420); Nos. 18,195-18,198 (Ghent, 1459-1462, 1466-1467, 1482-1484); Nos. 18,103-18,116 (Bruges, 1455-1482); No. 18,203 (Namur, 1421-1433); Algemcen Rijksarchief, Acquits de Lille, Liasses Nos. 936-937 (Ghent, 1410-1447); No. 1512 (Bruges, 1454-1456, 1466-1467; Mechelen, 1454-1456, 1459-1460); Archives départementales du Nord (Lille), Chambre des Comptes, Série B., Nos. 644/15.939 and 19.960/19.312 (Bruges, 1454-1456); No. 1606 (Ghent, 1441-1442).

(c) Additional mints, in Table 6: ARA, Rekenkamer, Registers Nos. 18,106-18,108 and 18,116-18,118 (Bruges); Nos. 18,196-18,199 (Ghent).

(d) Monetary Ordinances and Statistics: Munro (1981, 1983a, 1984); Spufford (1970); Deschamps de Pas (1861, 1862, 1866, 1869); Rouyer (1847, 1848); Gaillard (1856, Vol. 2); Cockshaw (1971); Bartier and Van Nieuwenhuysen (1965).

Note: in a book review in Revue du Nord 69 (1986), 542-543, Alain Derville charged that in my earlier work 1 had missed mint accounts for Ghent (1422, 1433, 1441-1442), Namur (1432-1433), Valenciennes (1433), and Zevenbergen (1433). He is mistaken: all of these accounts are in fact included in my earlier monetary publications (and those for Ghent and Namur, in this one).

\section{Commodity Prices: Table 2}

Verlinden and Scholliers (1965-1969, Vol. 1, pp. 44-45: peas; Vol. 2, pp. 33-35: wheat; pp. 64-66: butter; pp. 67-69: cheese); Van der Wee (1963, Vol. 1, pp. 204-206; eggs; pp. 277-281: herring; pp. 294-298: Rhine wine); and Munro (1984, pp. 62-71, 102-109: Flemish price index).

\section{REFERENCES}

Bartier, J., and Van Nieuwenhuysen, A. (Eds.). (1965), Les ordonnances de Philippe le Hardi, de Marguerite de Mäle, et de Jean Sans Peur, 1381 1419. Vol. I. Brussels: Palais des Académies.

Bautier, R. H. (1951), “'L'or et l'argent en occident de la fin du XIIIle siècle au début du XIVe siècle." Académie des inscriptions et belles-lettres: Comptes rendus des séances de l'année. Paris. Pp. 169-174.

Bernocchi, M. (1976), Le monete della repubblica fiorentina, 3 vols. Florence: Leo S. Olschki.

Bigwood, G. (1921-1922), Le régime juridique et économique du commerce de l'argent dans la Belgique du moyen-âge. 2 vols. Brussels: Académie Royale de Belgique, Classe des Lettres XIV. 
Blockmans, W. P. (1973), "La participation des sujjets flamands à la politique monétaire des ducs de Bourgogne (1384-1500)." Revue belge de numismatique et de sigillographie 119, 103-134.

Blockmans, W. P. (1974), "Autocratie ou polyarchie? La lutte pour le pouvoir politique en Flandre de 1482 à 1492, d'après des documents inédits." Bulletin de la commission royale d'histoire $140,257-368$.

Blockmans, W. P. (1979), "Devaluation, Coinage, and Seignorage under Louis de Nevers and Louis de Male, Counts of Flanders, 1330-84." In N. J. Mayhew (Ed.), Coinage in the Low Countries, 880-1500: Third Oxford Symposium on Coinage and Monetary History (British Archeological Reports, International Series 54). Oxford. Pp. 69-94.

Blunt, C. E., and Brand, J. D. (1970), "The Mint Output of Henry III." British Numismatic Journal 39, 61-66.

Bordo, M. D. (1986), "Money, Deflation, and Seigniorage in the Fifteenth Century." Journal of Monetary Economics 18, 337-346.

Braunstein, P. (1983), "Innovations in Mining and Metal Production in Europe in the Late Middle Ages." Journal of European Economic History 12, 573-591.

Brooke, G. C., and Stokes, E. (1929), "Tables of Bullion Coined from 1337 to 1550 ." The Numismatic Chronicle, 5th ser. 9, 27-69.

Cannan, E. (1926), Money: Its Connexion with Rising and Falling Prices. London: King $\&$ Son. 5 th ed.

Challis, C. E. (1978), The Tudor Coinage. Manchester: University Press.

Chalon, R. (1847), "Trois jetons du XVe siècle." Revue belge de numismatique (formerly Revue de la numismatique belge) 3, 67-69.

Cipolla, C. M. (1956), Money, Prices, and Civilization in the Mediterranean World: Fifth to Seventeenth Century. Princeton, NJ: Princeton Uniy. Press (Reissued New York: Gordian Press, 1967).

Cipolla, C. M. (1963), "Currency Depreciation in Medieval Europe." Economic History Review, 2nd ser. 15, 413-422. Reprinted with a few changes in Sylvia Thrupp (Ed.), (1964), Change in Medieval Society: Europe North of the Alps. New York: AppletonCentury. Pp. 227-236.

Cipolla, C. M. (1982), The Monetary Policy of Fourteenth-Century Florence. Berkeley/Los Angeles: Univ. of California Press.

Cockshaw, P. (1970-1971), "A propos de la circulation monétaire entre la Flandre et le Brabant de 1384 à 1390." Contributions à l'histoire économique et sociale 6, 107141.

Courtenay, W. J. (1972-1973), "Token Coinage in the Administration of Poor Relief during the Later Middle Ages." Journal of Interdisciplinary History 3, 175-195.

Craig, J. (1953), The Mint: A History of the London Mint from A.D. 287 to 1948. Cambridge: University Press.

Crump, C. G., and Johnson, C. (1913), "Tables of Bullion Coined Under Edward I, II, and III." The Numismatic Chronicle, 4th ser. 13, 200-245.

Day, J. (1978), "The Great Bullion Famine of the Fifteenth Century." Past and Present $79,3-54$.

De Limburg-Stinum, T. (Ed.). (1898), Cartulaire de Louis de Male, 1348-1358, Bruges: De Plancke.

De Roover, R. (1948), Money, Banking, and Credit in Mediaeval Bruges: Italian MerchantBankers, Lombards and Money-Changers, A Study in the Origins of Banking. Cambridge, MA: Mediaeval Academy.

De Roover, R. (1949), Gresham on Foreign Exchange. Cambridge, MA: Harvard Univ. Press.

Deschiamps de Pas, L. $(1861,1862,1866)$, "Essai sur l'histoire monétaire des comtes de 
Flandre de la maison de Bourgogne." Revue numismatique, 2nd ser. 6, 106-139, 211$237,458-478 ; 7,117-143,351-365,460-480 ; 11,172-219$.

Deschamps de Pas, L. (1863), Essai sur l'histoire monétaire des comtes de Flandre de la maison de Bourgogne. Paris.

Deschamps de Pas, L. (1869), "Essai sur l'histoire monétaire des comtes de Flandre de la maison d'Autriche." Revue numismatique, 2nd ser. 14, 86-114.

Deschamps de Pas, L. (1874), Essai sur l'histoire monétaire des comtes de Flandre de la maison d'Autriche et classement de leurs monnaies (1482-1556). Paris: Arnous de Rivière.

Dieudonné, A. (1933), "Les doubles cornus de Philippe le Bel et les origines de la mite flamande." Revue belge de numismatique 85, 23-41.

Feavearyear, A. E. (1963), The Pound Sterling: A History of English Money. Oxford: Clarendon Press. 2nd revised ed. by E. Victor Morgan.

Gaillard, V. (Ed.). (1856), Recherches sur les monnaies des comtes de Flandre, Vol. II: Sous les règnes de Louis de Crécy et de Louis de Male. Ghent: H. Hoste.

Ghyssens, J. (1970), "Les débuts de la mite et de la monnaie de compte en Flandre." Revue belge de numismatique et de sigillographie 116, 181-189.

Ghyssens, J. (1974), "Le monnayage d'argent en Flandre, Hainaut, et Brabant au début de la Guerre de Cent Ans." Revue belge de numismatique et de sigillographie 120, 109-191.

Great Britain, Parliament (1777), Rotuli Parliamentorum ut et petitiones et placita in parliamento, Vol. VI. London.

Grierson, P. (1963), "Coin Wear and the Frequency Table." The Numismatic Chronicle, 7th ser. 3, 1-16. Reprinted in Grierson (1979), Later Medieval Numismatics, No. xix.

Grierson, P. (1975), Numismatics. London: Oxford Univ. Press.

Grierson, P. (1976), "Medieval Numismatics." In J. Powell (Ed.), Medieval Studies: An Introduction. Syracuse. Pp. 103-136. Reprinted in Later Medieval Numismatics, No. i.

Grierson, P. (1979), Later Medieval Numismatics (11th-16th Centuries): Selected Studies. London: Variorum Reprints.

Holden, J. (1955), The History of Negotiable Instruments in English Law. London: Athlone Press.

Johnson, C. (Ed. and trans.). (1956), The De Moneta of Nicholas Oresme and English Mint Documents. London: Nelson.

Lane, F. C., and Mueller, R. (1985), Money and Banking in Medieval and Renaissance Venice, Vol. I: Coins and Moneys of Account. Baltimore/London: Johns Hopkins Univ. Press.

Mayhew, N. (1974a), "Numismatic Evidence and Falling Prices in the Fourteenth Century." Economic History Review, 2nd ser. 27, 1-15.

Mayhew, N. (1974b), "The Monetary Background to the Yorkist Recoinage of 1464-1471." British Numismatic Journal 44, 62-73.

Meert, C. (1970), "Les ateliers des petites seigneuries belges sous la période bourguignonne et la domination espagnole." Revue belge de numismatique et de sigillographie 116, 209-211.

Miskimin, H. A. (1963), Money, Prices, and Foreign Exchange in Fourteenth-Century France. New Haven/London: Yale Univ. Press.

Miskimin, H. A. (1964), "Monetary Movements and Market Structure: Forces for Contraction in Fourteenth- and Fifteenth-Century England." Journal of Economic History 24, 478490.

Miskimin, H. A. (1975), The Economy of Early Renaissance Europe, 1300-1460. Cambridge/New York: Cambridge Univ. Press.

Miskimin, H. A. (1983), "Money and Money Movements in France and England at the 
End of the Middle Ages." In J. F. Richards (Ed.), Precious Metals in the Later Medieval and Early Modern Worlds. Durham, NC: Carolina Academic Press. Pp. 7996.

Miskimin, H. A. (1984), Money and Power in Fiffeenth-Century France. New Haven/London: Yale Univ. Press.

Miskimin, H. A. (1985), "L'or, l'argent, et la guerre dans la France médiévale." Annales: Economies, sociétés, civilisations 40, 171-184.

Mitchiner, M., and Skinner, A. (1983), "English Tokens, c. 1200 to 1425." British Numismatic Journal 53, 29-77.

Mitchiner, M., and Skinner, A. (1984), "English Tokens, c. 1425 to 1672." British Numismatic Journal 54, 86-163.

Monroe, A. E. (1923), Monetary Theory Before Adam Smith. Cambridge, MA: Harvard Economic Studies. Vol. 25.

Munro, J. H. (1972), "An Aspect of Medieval Public Finance: The Profits of Counterfeiting in the Fifteenth-Century Low Countries." Revue belge de numismatique et de sigillographie 118, 127-148.

Munro, J. H. (1973), Wool, Cloth, and Gold: The Struggle for Bullion in Anglo-Burgundian Trade, ca. 1340-1478. Brussels/Toronto: Editions de l'Université de Bruxelles.

Munro, J. H. (1974), "Billon-Billoen-Billio: From Bullion to Base Coinage." Revue belge. de philologie et d'histoire 52, 293-305.

Munro, J. H. (1975), "The Purchasing Power of Coins and of Wages in the Low Countries and England, 1500-1514." In R. Mynors and W. Ferguson (Eds.), The Correspondence of Erasmus, Vol. I: 1501-1514, Toronto: Univ. of Toronto Press. Pp. 307-345.

Munro, J. H. (1979a), "Monetary Contraction and Industrial Change in the Late Medieval Low Countries, 1335-1500." In N. Mayhew (Ed.), Coinage in the Low Countries, 880-1500: Third Oxford Symposium on Coinage and Monetary History (British Archeological Reports, International Series 54). Oxford. Pp. 95-161.

Munro, J. H. (1979b), "Bullionism and the Bill of Exchange in England, 1272-1663." In Center for Medieval and Renaissance Studies, UCLA (Ed.), The Dawn of Modern Banking. New Haven/London: Yale Univ. Press. Pp. 169-239.

Munro, J. H. (1981), "Mint Policies, Ratios, and Outputs in England and the Low Countries, 1335-1420." The Numismatic Chronicle, 8th ser. 1, 71-116.

Munre, J. H. (1983a), "Bullion Flows and Monetary Contraction in Late-Medieval England and the Low Countries." In J. F. Richards (Ed.), Precious Metals in the Later Medieval and Early Modern Worlds. Durham, NC: Carolina Academic Press. Pp. 97-158.

Munro, J. H. (1983b), "Economic Depression and the Arts in the Fifteenth-Century Low Countries." Renaissance and Reformation 19, 235-250.

Munro, J. H. (1984), "Mint Outputs, Money, and Prices in Late-Medieval England and the Low Countries." In E. Van Cauwenberghe and F. Irsigler (Eds.), Münzprägung, Geldumlauf und Wechselkurse/Minting, Monetary Circulation and Exchange Rates: Akten des 8th International Economic History Congress (Trierer Historische Forschungen. Trier. Vol. 7). Pp. 31-122.

Nef, J. U. (1941), "Silver Production in Central Europe, 1450-1618." Journal of Political Economy 49, 575-591.

Nef, J. U. (1952), "Mining and Metallurgy in Medieval Civilisation." In M. Postan and E. Rich (Eds.), Cambridge Economic. History of Europe, Vol. II: Trade and Industry in the Middle Ages. Cambridge: Univ. Press. Pp. 430-493.

Patterson, C. C. (1972), "Silver Stocks and Losses in Ancient and Medieval Times." Economic History Review, 2nd ser. 25, 205-235.

Piot, C. (1842), "Mélanges." Revue belge de numismatique (Revue de la numismatique belge) $1,151-154$. 
Piot, C. (1855a), "Notice sur des monnaies noires de Heusden, Born, Limbricht, Brabant, Hainaut et Malines." Revue belge de numismatique 11, 36-60.

Piot, C. (1855b), "Notice sur des monnaies noires de Flandre, Malines, Namur, Luxembourg et Megen." Revue belge de numismatique 11, 198-221.

Piot, C. (1856a), "Notice sur des monnaies de Kessenich, Hornes, Grave, Randerode, Stevenswerd et Reckheim." Revue belge de numismatique 12, 76-95.

Piot, C. (1856b), "Notice sur des monnaies noires et de billon de Reckheim et de Stein." Revue belge de numismatique 12, 309-323.

Postan, M. M. (1928), "Credit in Medieval Trade." Economic History Review, 1st ser. 1, 234-261. Reprinted in Postan (1973), Medieval Trade and Finance. Cambridge Univ. Press. Pp. 1-27.

Postan, M. (1930), "Private Financial Instruments in Medieval England." Vierteljahrschrift für Sozial- und Wirtschaftsgeschichte 23. Reprinted in his Medieval Trade and Finance. Pp. 28-64.

Rouyer, J. (1847, 1848), "Recherches sur la numismatique dn comté de Flandre considéré dans les monnaies noires durant la suzeraineté française." Revue numismatique $\mathbf{1 2}$, $437-462 ; 13,404-434$.

Spengler, J. P. (1965-1966), “Coin Shortage: Modern and Pre-Modern." National Banking Review 3, 201-216.

Spooner, F. C. (1972), The International Economy and Monetary Movements in France, 1493-1725. Cambridge, MA: Harvard Economic Studies. Vol. 138.

Spufford, P. (1964), "Burgundian Double Patards in Late-Medieval England." British Numismatic Journal 33, 110-117.

Spufford, P. (1966a), "Coinage, Taxation, and the Estates General of the Burgundian Netherlands." Standen en Landen (Anciens pays et assemblées d'états) 40, 63-88.

Spufford, P. (1966b), "Assemblies of Estates, Taxation, and the Control of Coinage in Medieval Europe:" Etudes presentées à la commission internationale pour l'histoire des assemblées d'états (XII Congrès international des sciences historiques) 31, 115 130.

Spufford, P. (1970), Monetary Problems and Policies in the Burgundian Netherlands, 14331496. Leiden: E. J. Brill.

Spufford, P. (1986), Handbook of Medieval Exchange. London: Royal Historical Society Handbook No. 13.

Tourneur, V. (1928), "'La trouvaille de la Petite rue Ravenstein, à Bruxelles." Revue belge de numismatique 80, 123-125.

Usher, A. P. (1943), The Early History of Deposit Banking in Mediterranean Europe. Cambridge, MA: Harvard Univ. Press. Vol. 1.

Van der Wee, H. (1963), The Growth of the Antwerp Market and the European Economy (14th-16th Centuries), 3 vols. The Hague: Martinus Nijhoff.

Van der Wee, H. (1969), "International Business Finance and Monetary Policy in Western Europe, 1384-1410." Business History Review 43, 374-376.

Van der Wee, H. (1977), "Monetary, Credit, and Banking Systems." In E. E. Rich and C. H. Wilson (Eds.), Cambridge Economic History of Europe, Vol. V: The Economic Organization of Early Modern Europe. Cambridge: Univ. Press. Pp. 290-393.

Van der Wee, H. (1978), "Prices and Wages as Development Variables: A Comparison between England and the Southern Netherlands, 1400-1700." Acta Historiae Neerlandicae 10, 58-78.

Van Keymeulen, A. (1973), Les trésors monétaires modernes trouvés en Belgique, 14341830. Brussels: Cercle d'Etudes numismatiques.

Van Gelder, H. E., and Hoc, M. (1960), Les monnaies des Pays-Bas bourguignons et espagnols, 1434-1713: Répertoire générale. Amsterdam: J. Schulman. 
Van Uytven, R. (1975), "Politiek en economie: de crisis der late XVe eeuw in de Nederlanden." Revue belge de philologie et d'histoire 53, 1097-1149.

Van Werveke, H. (1949a), De muntslag in Vlaanderen onder Lodewijk van Male (Mededelingen van de koniklijke Vlaamse Academie voor Wetenschappen, Letteren, en Schone Kunsten, Klasse der Letteren, no. X:5). Brussels.

Van Werveke, H. (1949b), "Currency Manipulation in the Middle Ages: The Case of Louis de Male, Count of Flanders." Transactions of the Royal Historical Society, 4th ser. 31, 115-127.

Verlinden, C., Craeybeckx, J., and Scholliers, E. (Eds.). (1959-1965), Dokumenten voor de geschiedenis van prijzen en lonen in Vlaanderen en Brabant (XVe-XVIII eeuw), 4 vols. Bruges: De Tempel. 